
Nevada
Environmental
Restoration
Project

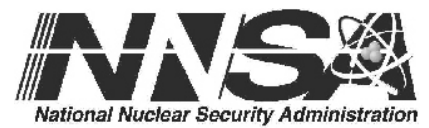

Streamlined Approach For

Environmental Restoration Plan for

Corrective Action Unit 116: Area 25

Test Cell C Facility, Nevada Test

Site, Nevada

Controlled Copy No.:

Revision: 0

July 2006

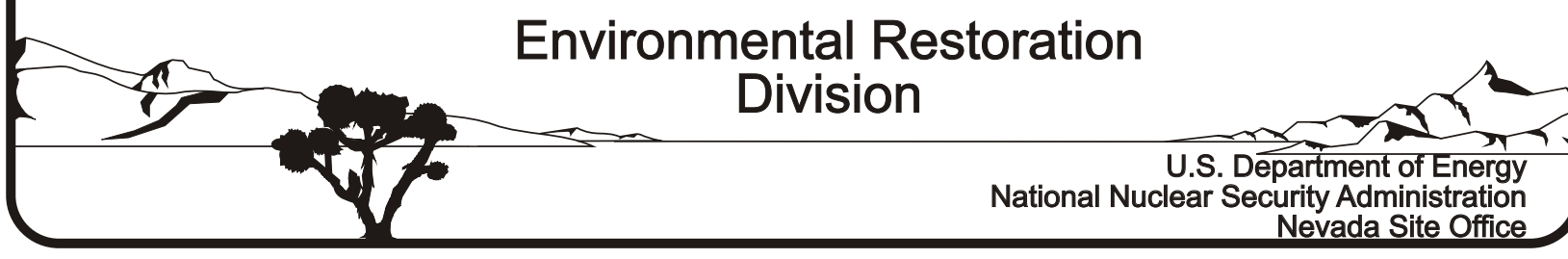




\title{
DISCLAIMER
}

Reference herein to any specific commercial product, process, or service by trade name, trademark, manufacturer, or otherwise, does not necessarily constitute or imply its endorsement, recommendation, or favoring by the United States Government or any agency thereof or its contractors or subcontractors.

This report has been reproduced directly from the best available copy.

Available for sale to the public from:

\author{
U.S. Department of Commerce \\ National Technical Information Service \\ 5285 Port Royal Road \\ Springfield, VA 22161-0002 \\ Telephone: (800) 553-6847 \\ Fax: (703) 605-6900 \\ Email: orders@ntis.gov \\ Online ordering: http://www.ntis.gov/ordering.htm
}

Available electronically at http://www.osti.gov/bridge.

Available for a processing fee to the U.S. Department of Energy and its contractors, in paper, from:

U.S. Department of Energy

Office of Scientific and Technical Information

P.O. Box 62

Oak Ridge, TN 37831-0062

Telephone: (865) 576-8401

Fax: (865) 576-5728

E-mail: reports@adonis.osti.gov 


\title{
STREAMLINED APPROACH FOR ENVIRONMENTAL RESTORATION PLAN FOR CORRECTIVE ACTION UNIT 116: AREA 25 TEST CELL C FACILITY NEVADA TEST SITE, NEVADA
}

\author{
U.S. Department of Energy \\ National Nuclear Security Administration \\ Nevada Site Office \\ Las Vegas, Nevada
}

Controlled Copy No.:

Revision: 0

July 2006 
THIS PAGE INTENTIONALLY LEFT BLANK 


\section{STREAMLINED APPROACH FOR ENVIRONMENTAL RESTORATION PLAN FOR CORRECTIVE ACTION UNIT 116: AREA 25 TEST CELL C FACILITY NEVADA TEST SITE, NEVADA}

Approved By:

Kevin J. Cabble

Federal Sub-Project Director

Environmental Restoration Project

Approved By:

Janet L. Appenzeller-Wing

Federal Project Director

Environmental Restoration Project

Date:

Date: 
THIS PAGE INTENTIONALLY LEFT BLANK 


\section{TABLE OF CONTENTS}

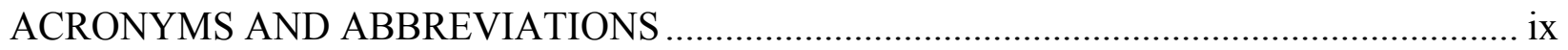

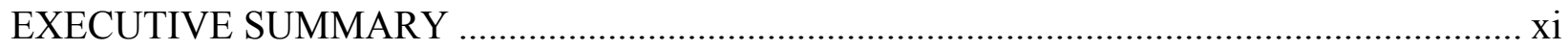

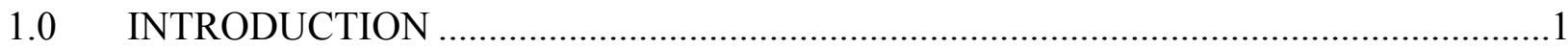

1.1 Streamlined ApProach for EnVIRONMENTAL Restoration Process .............. 1

1.2 SUMMARY OF PROPOSED CORRECTIVE ACTIONS .................................................... 3

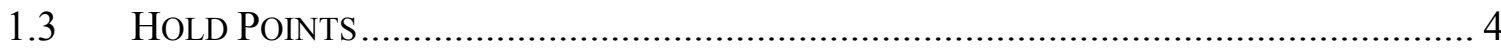

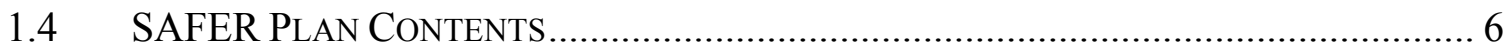

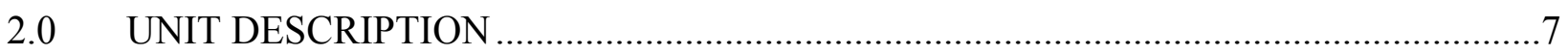

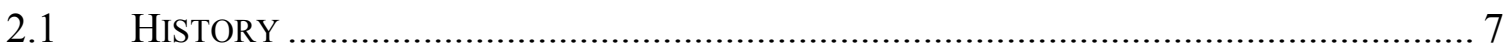

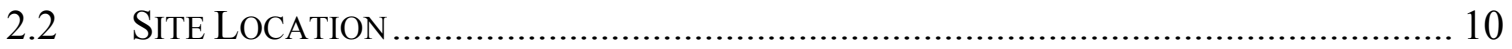

2.3 PROCESS KNOWLEDGE........................................................................... 10

2.3.1 Radioactive Contamination.................................................................... 10

2.3.2 Hazardous and Regulated Materials ....................................................... 11

2.3.3 Asbestos-Containing Material ........................................................... 11

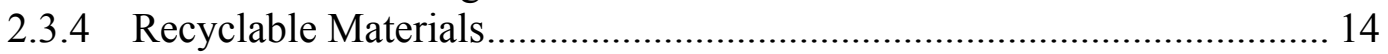

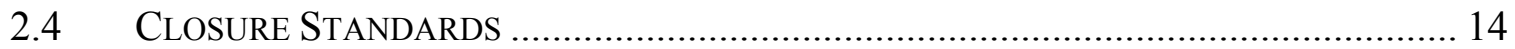

2.4.1 Concrete Foundation........................................................................ 15

2.4.2 Below-Grade Piping.............................................................................. 17

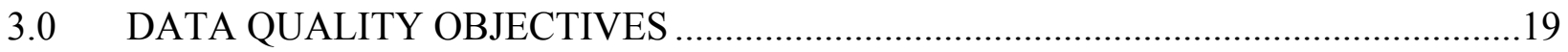

3.1 Summary of Data Quality ObJectives AnaLysis .......................................... 19

3.1.1 State the Problem (Step 1) .................................................................... 19

3.1.2 Identify the Decisions (Step 2) …………………………………….... 20

3.1.3 Identify the Inputs to the Decisions (Step 3) ............................................ 21

3.1.4 Define the Study Boundaries (Step 4) ………………………................ 22

3.1.5 Develop a Decision Rule (Step 5) ......................................................... 23

3.1.6 Specify Tolerable Limits on Decision Errors (Step 6)………………..... 24

3.1.7 Optimize the Design (Step 7) ................................................................ 25

3.2 Results OF THE DATA QuALITY OBJECTIVES ANALYSIS....................................... 26

3.2.1 Action Level Determination and Basis ................................................... 26

3.2.2 Hypothesis Test............................................................................. 26

3.2.3 Statistical Model ............................................................................. 26

3.2.4 Design Description/Option ........................................................................ 27

3.2.5 Conceptual Site Model........................................................................... 27

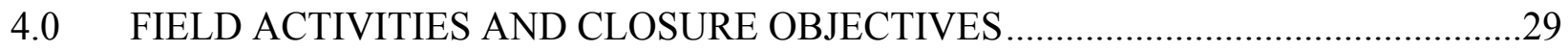

4.1 CONTAMINANTS OF POTENTIAL CONCERN........................................................... 29

4.1.1 Asbestos-Containing Material ……………........................................... 30

4.1.2 Polychlorinated Biphenyls ................................................................... 30

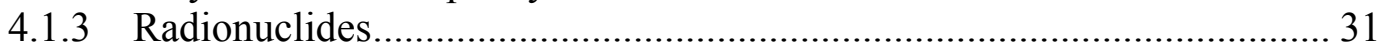

4.1.4 Resource Conservation and Recovery Act Metals...................................... 31

4.1.5 Other Hazardous Constituents ............................................................. 32 


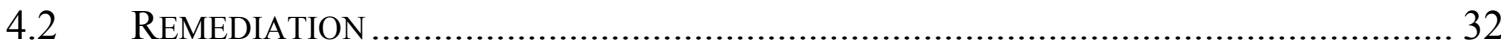

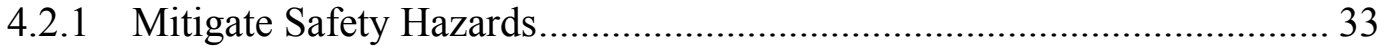

4.2.2 Hazardous and Regulated Waste Removal ............................................. 33

4.2.3 Draining Lubricants/Fluids from Equipment........................................... 35

4.2.4 Removal of Radiologically Impacted Items or Materials ....................... 35

4.2.5 Initial Characterization Surveys........................................................ 36

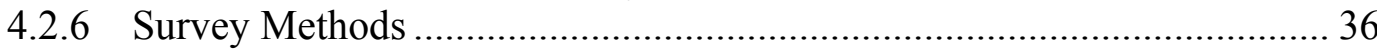

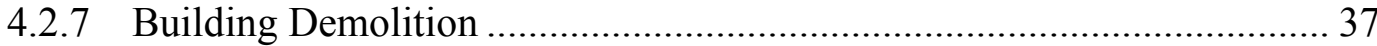

4.2.8 Post-Demolition Surveys ................................................................. 38

4.2.9 Decontamination of Radiologically-Impacted Surfaces ........................ 38

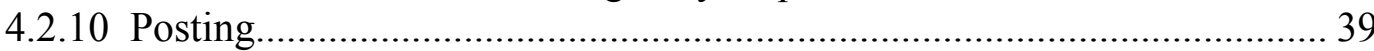

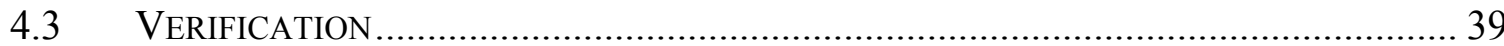

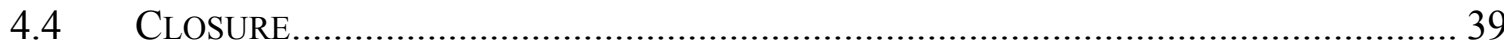

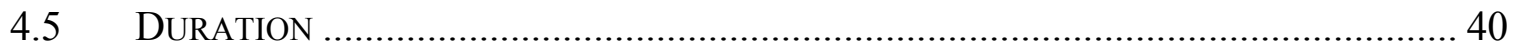

5.0 REPORTS AND RECORDS AVAILABILITY .......................................................43

5.1 FIELD MANAGEMENT Plan ............................................................................ 43

5.2 NATIONAL EnVIRONMENTAL Policy ACT CHECKLIST.......................................... 43

5.3 DAILY FIELD REPORTS............................................................................ 43

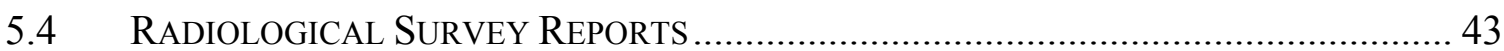

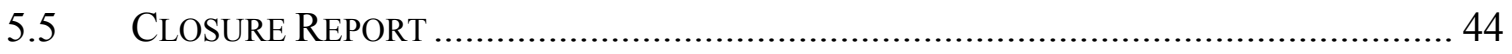

6.0 INVESTIGATION/REMEDIATION WASTE MANAGEMENT ..............................45

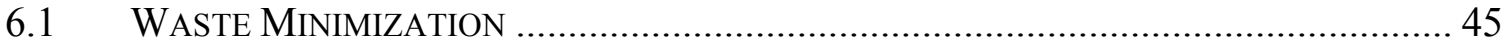

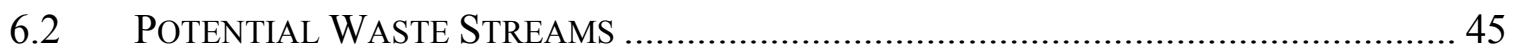

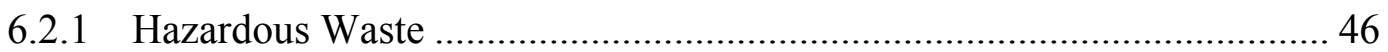

6.2.2 Asbestos-Containing Material .......................................................... 46

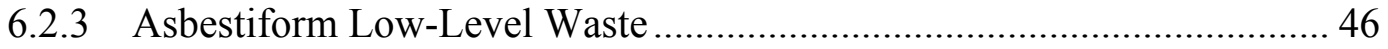

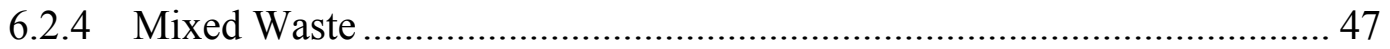

6.2.5 Low-Level Radioactive Waste........................................................... 47

6.2.6 Polychlorinated Biphenyl Bulk Product Waste ...................................... 48

6.2.7 Reusable or Recyclable Materials........................................................... 48

7.0 QUALITY ASSURANCE/QUALITY CONTROL ….........................................51

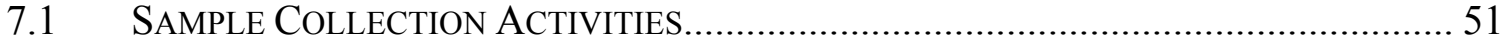

7.2 APPLICABLE LABORATORY/ANALYTICAL DATA QUALITY INDICATORS ................ 51

7.2.1 Precision........................................................................................... 52

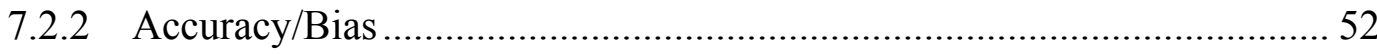

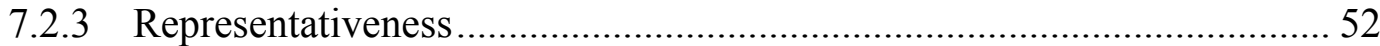

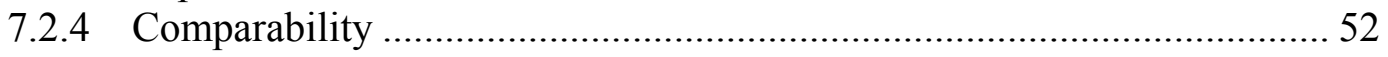

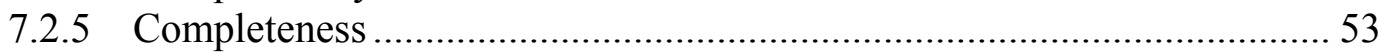

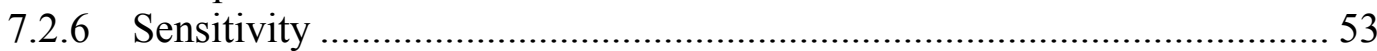

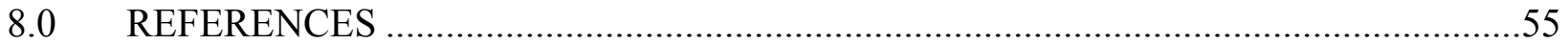




\section{FIGURES}

Figure 1. Location of CAU 116: AREa 25Test Cell C Facility ................................. 2

Figure 2. Project Flow Diagram and Hold Points .................................................. 5

Figure 3. Test Cell C Facility AND Associated Structures..................................... 9

Figure 4. ASBESTOS-WrapPED EleCtRIC CORD ................................................................ 12

Figure 5. Asbestos-WrapPed Electrical CABLE ..................................................... 12

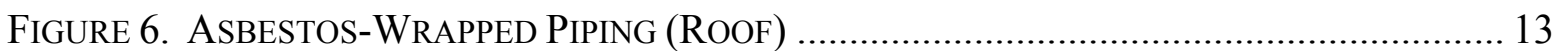

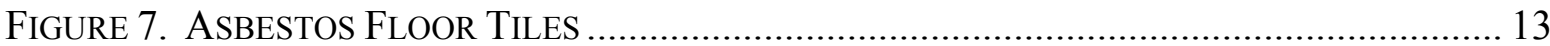

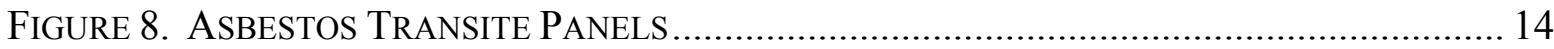

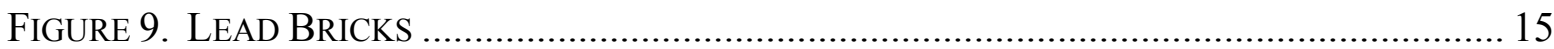

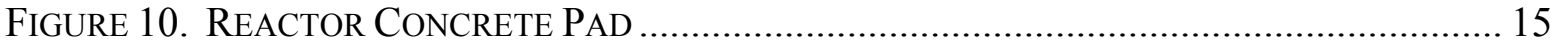

Figure 11. BELOW-GRound PIPING AND FloOR Drains ................................................. 17

Figure 12. REPRESENTATIVE MERCURY CONTAINING ITEM ............................................. 32

\section{TABLES}

Table 1. Surface Contamination Values in Disintegrations Per Minute

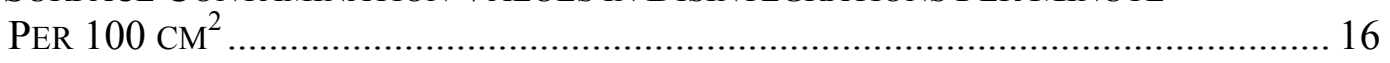

TABle 2. Summary of Conceptual Site Model for CAU 116 .................................. 20

TABLE 3. SAMPLE ANALYSIS REQUIREMENTS .......................................................... 26

TABLE 4. CONTAMINANTS OF CONCERN ........................................................................ 30

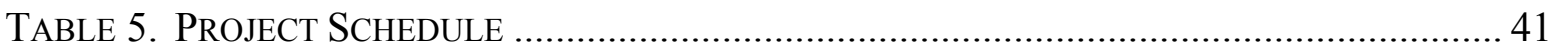

TABLE 6. LABORATORY/ANALYTICAL DATA QUALITY INDICATORS .................................. 53

\section{APPENDICES}

ApPENDix A. Project Organization

Appendix B. Nevada Division of Environmental Protection Comments LIBRARY DISTRIBUTION LIST 
SAFER Plan - CAU 116

Section: Table of Contents

Revision: 0

Date: July 2006

THIS PAGE INTENTIONALLY LEFT BLANK 


\section{ACRONYMS AND ABBREVIATIONS}

ACM Asbestos-Containing Material

BMP Best Management Practice

CAS Corrective Action Site

CAU Corrective Action Unit

CD Company Directive

CFR Code of Federal Regulations

$\mathrm{cm}^{2} \quad$ square centimeter

Co Cobalt

COC Contaminants of Concern

COPC Contaminants of Potential Concern

Cs Cesium

CSM Conceptual Site Model

D\&D Decontamination and Decommissioning

DOE U.S. Department of Energy

DQI Data Quality Indicator(s)

DQO Data Quality Objective(s)

E-MAD Engine Maintenance, Assembly, and Disassembly

EPA U.S. Environmental Protection Agency

ER Environmental Restoration

ES\&H Environment, Safety, and Health

$\mathrm{Eu} \quad$ Europium

FFACO Federal Facility Agreement and Consent Order

FMP Field Management Plan

$\mathrm{ft}^{2} \quad$ square foot (feet)

HP Health Physicist

HW Hazardous Waste

I Iodine

ISOCS In-Situ Object Counting System

LLW Low-Level Waste

$\mathrm{m}^{2} \quad$ square meter(s)

$\mathrm{M} \& \mathrm{O} \quad$ Management and Operations

MW $\quad$ Mixed Waste 


\section{ACRONYMS AND ABBREVIATIONS (continued)}

mrem milliroentgen equivalent man millirem

NCRP National Council on Radiation Protection

NDEP Nevada Division of Environmental Protection

NNSA/NSO U.S. Department of Energy, National Nuclear Security Administration Nevada Site Office

NNSA/NV U.S. Department of Energy, National Nuclear Security Administration Nevada Operations

NRDS Nuclear Rocket Development Station

NTS Nevada Test Site

NV/YMP Nevada/Yucca Mountain Project

PCB Polychlorinated Biphenyl(s)

$\mathrm{Pu} \quad$ Plutonium

QA Quality Assurance

QAPP Quality Assurance Project Plan

QC quality control

RadCon Radiological Control

Ra Radium

RCRA Resource Conservation and Recovery Act

RCT Radiological Control Technician

R-MAD Rocket Maintenance, Assembly, and Disassembly

SAFER Streamlined Approach for Environmental Restoration

SAP Sampling and Analysis Plan

$\mathrm{Sr} \quad$ Strontium

SSHASP Site-Specific Health and Safety Plan

TCA Test Cell A

TCC Test Cell C

Th Thorium

TCLP Toxicity Characteristic Leaching Procedure

TSCA Toxic Substances Control Act

U Uranium

WMP Waste Management Plan

yr year




\section{EXECUTIVE SUMMARY}

Corrective Action Unit (CAU) 116: Area 25 Test Cell C Facility is listed in Appendix III of the Federal Facility Agreement and Consent Order (FFACO) of 1996. CAU 116 is located at the Test Cell C (TCC) Facility northwest of the intersection of F and J Roads in Area 25 of the Nevada Test Site (NTS). CAU 116 includes the following Corrective Action Sites (CASs):

- CAS 25-23-20, Nuclear Furnace Piping

- CAS 25-41-05, Test Cell C Facility

CAS 25-41-05 is described in the FFACO as the TCC Facility, but is actually only Building 3210 and the attached concrete shield wall. CAU 116 will be closed by demolishing Building 3210, the shield wall, and the Nuclear Furnace Piping. In addition, as a best management practice (BMP), all remaining buildings and structures within the TCC Facility fence will be demolished. This includes the dewars and associated piping; Buildings 3203, 3207, 3208 (water tower), 3211, 3220, 3230, 3232; and the Nuclear Rocket Development Station (NRDS) \#4 Substation.

Numerous nuclear tests were conducted at TCC, including tests related to the Kiwi, Phoebus, Nuclear Rocket Experimental, Peewee, and Nuclear Furnace series nuclear rockets developed under the NRDS, which was jointly administered by the Atomic Energy Commission and the National Aeronautics and Space Administration, Space Nuclear Propulsion Office. These tests were conducted between 1963 and 1969. In 1969, the reactor development, engine testing, and nuclear rocket development activities were concluded at the NRDS. Building 3210 was constructed in 1961 as part of the TCC Facility and was in operation until 1973 when it was placed into long-term mothball status. In 1978 the facility, excluding the roof, was radiologically decontaminated to the standards of the time, and released for reuse in 1981 . Since January 1997, TCC has been maintained under the NTS decontamination and decommissioning surveillance and maintenance program.

The closure of CAU 116 will be accomplished by completing the following closure activities:

- Perform initial characterization surveys.

- Remove all identified regulated or hazardous materials, including:

- Fill all trenches and large cracks on the reactor concrete pad with grout or similar material.

- Demolish Building 3210 (to grade), the concrete shield wall, and the nuclear furnace piping; place as much of this demolition debris as space allows into the remaining basement structure.

- As a BMP, demolish all other buildings and structures within the TCC Facility fence, including the dewars and associated piping; Buildings 3203, 3207, 3208 (water tower), 3211, 3220 (technical support center), 3230 (motor generator building), 3232 (pump house); and the NRDS \#4 Substation. Place as much of the demolition debris into the basement of Building 3210 as space allows.

- Mound or cap the basement structure after filling with debris. 


\section{EXECUTIVE SUMMARY (continued)}

- Following demolition, use non-aggressive methods (e.g., high-efficiency particulate air vacuums), to decontaminate/remove any remaining transferable radioactive contamination from the concrete slabs within the TCC Facility fence.

- Perform final release and confirmatory radiological surveys to establish proper controls (postings) for the concrete slabs within the TCC Facility fence.

- Install radiological and use restriction postings, as necessary. 


\subsection{INTRODUCTION}

This Streamlined Approach for Environmental Restoration (SAFER) Plan identifies the activities required for the closure of Corrective Action Unit (CAU) 116, Area 25 Test Cell C Facility. The Test Cell C (TCC) Facility is located in Area 25 of the Nevada Test Site approximately 25 miles northwest of Mercury, Nevada (Figure 1). CAU 116 is currently listed in Appendix III of the Federal Facility Agreement and Consent Order (FFACO, 1996) and consists of two Corrective Action Sites (CASs):

- CAS 25-23-20, Nuclear Furnace Piping

- CAS 25-41-05, Test Cell C Facility

CAS 25-41-05 is described in the FFACO as the TCC Facility but actually includes Building 3210 and attached concrete shield wall only.

CAU 116 will be closed by demolishing Building 3210, the attached concrete shield wall, and the nuclear furnace piping. In addition, as a Best Management Practice (BMP), all other buildings and structures within the TCC Facility fence will be demolished. These include the dewars and associated piping; Buildings 3203, 3207, 3208 (water tower), 3211, 3220, 3230, 3232; and the Nuclear Rocket Development Station (NRDS) \#4 Substation. Radiological surveys will be performed on the demolition debris to determine the proper disposal pathway. As much of the demolition debris as space allows will be placed into the Building 3210 basement structure. After filling to capacity with demolition debris, the basement structure will be mounded or capped and closed with administrative controls.

Prior to beginning demolition activities and according to an approved Sampling and Analysis Plan (SAP), representative sampling of surface areas that are known, suspected, or have the potential to contain hazardous constituents such as lead or polychlorinated biphenyls (PCBs) will be performed throughout all buildings and structures. Sections 2.3.2, 4.2.2.2, 4.2.2.3, 4.3, and 6.2.6.1 address the methodologies employed that assure the solid debris placed in the basement structure will not contain Contaminants of Concern above hazardous waste levels. The anticipated post-closure-posting requirements for the mounded/capped basement structure, as well as for the entire CAU, are addressed in Section 4.2.10.

The site contains radiologically impacted surfaces and hazardous materials. Based on review of the Preliminary Assessment information for CAU 116 and recent site inspections, there is sufficient process knowledge to close CAU 116 using the SAFER process.

\subsection{STREAMLINED APPROACH FOR ENVIRONMENTAL RESTORATION PROCESS}

CAUs that may be closed using the SAFER process have conceptual corrective actions that are clearly identified. Consequently, corrective action alternatives can be chosen prior to completing a corrective action investigation, given anticipated investigation results.

The SAFER process combines elements of the data quality objectives (DQO) process and the observational approach to plan and conduct closure activities. The DQO are used to identify the problem and define the type and quality of data needed to complete the investigation phase of the 


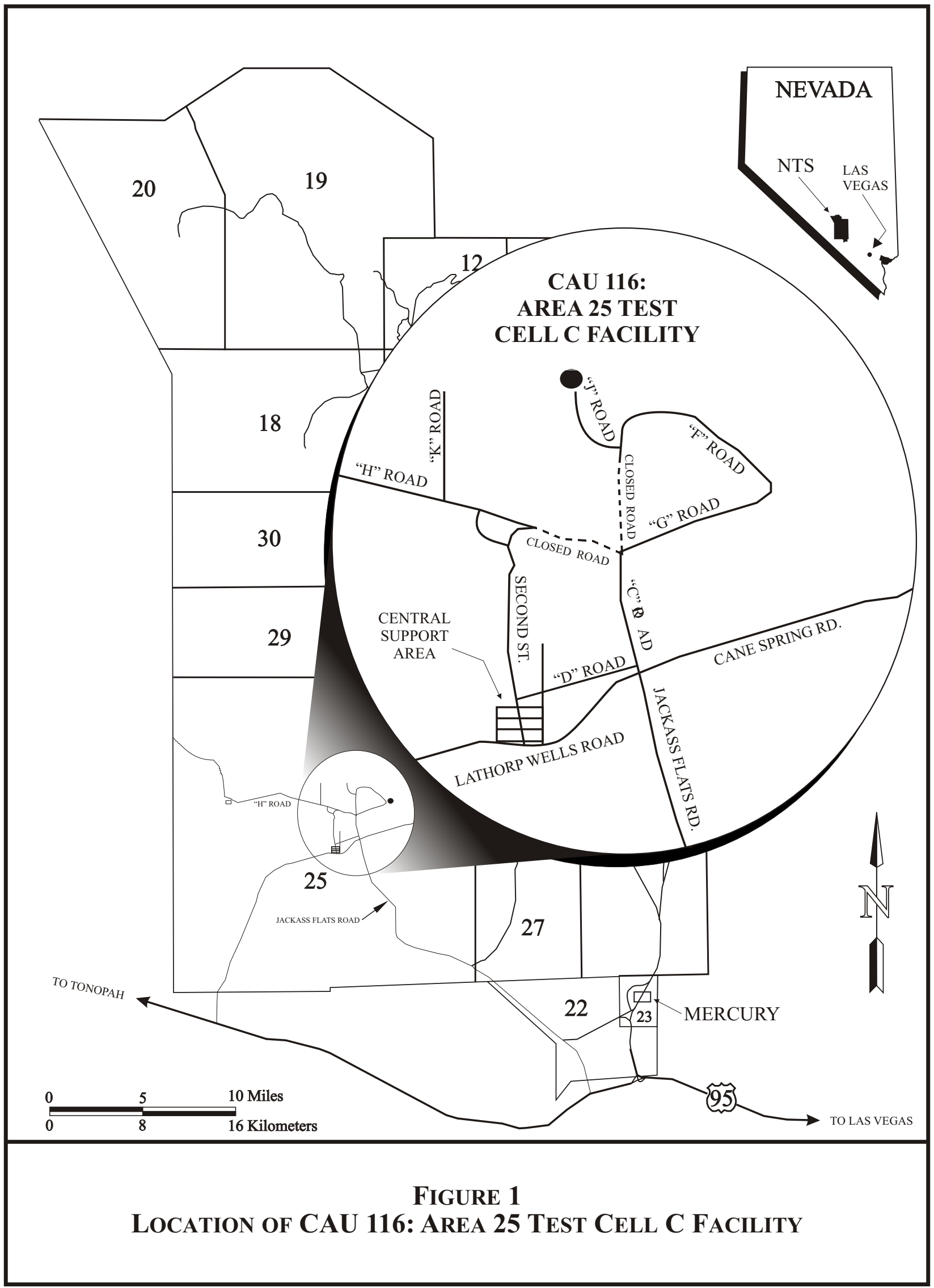


SAFER process. The purpose of the investigation phase is to verify the adequacy of existing information used to determine the chosen corrective action. The observational approach provides a framework for managing uncertainty during the planning and decision-making phases of the project.

The SAFER process allows for technical decisions to be made based on information gathered during site visits, interviews, meetings, research, and a consensus of opinion by the decontamination and decommissioning (D\&D) team members. Any uncertainties are addressed by documented assumptions that are verified by sampling and analysis, data evaluation, onsite observations, and contingency plans, as necessary.

Closure activities may proceed simultaneously with site characterization as sufficient data are gathered to confirm or disprove the assumptions made during selection of the corrective action. If, at any time during the closure process, new information is discovered that indicates that closure activities should be revised, closure activities will be reevaluated as appropriate.

Based on a detailed review of historical documentation, there is sufficient process knowledge to close CAU 116 using the SAFER process. The contaminants of concern (COC) have been determined and are discussed in Section 4.1.

\subsection{Summary of Proposed Corrective Actions}

Closure of CAU 116 will be accomplished by completing the following activities:

- Perform initial characterization surveys.

- Remove all regulated or hazardous materials, including:

- Fill all trenches and large cracks on the reactor concrete pad with grout or similar material.

- Demolish Building 3210 (to grade), the concrete shield wall, and the nuclear furnace piping; place as much demolition debris as space permits into the remaining basement structure.

- As a BMP, demolish all other buildings and structures within the TCC Facility fence, including the dewars and associated piping; Buildings 3203, 3207, 3208 (water tower), 3211 , 3220 (technical support center), 3230 (motor generator building), 3232 (pump house); and the NRDS \#4 Substation. Place as much of the demolition debris into the basement of Building 3210 as space allows.

- Mound or cap the basement structure after filling with debris.

- Remove transferable radioactive contamination, preferably using non-aggressive methods (e.g., high-efficiency particulate air vacuums, masslinn wipes, wet wipes, scrub brushes with soapy water or bio-degradable cleaning solutions/solvents, or strippable paint), from concrete surfaces within the TCC Facility fence. If non-aggressive decontamination methods are unsuccessful in reducing the contamination to acceptable levels, the Environmental Restoration (ER) Task Manager and ER Health Physicist (HP) will determine if more aggressive decontamination methods will be employed. Aggressive methods include but are not limited to the use of needle guns, scabblers, chippers, grit blasters, or jackhammers.

- Perform final release and confirmatory radiological surveys to establish proper controls (postings) of concrete foundations and the reactor concrete pad. 
- Install use restriction and appropriate radiological warning signs.

The final end state of the facility is "Demolished to Slab-on-Grade." Demolished to Slab-on-Grade includes demolition of all structures within the CAU boundary to their respective grade-level foundations. The closure strategy outlined in this SAFER Plan (1) improves facility condition to provide safe working conditions, (2) removes all Environment, Safety, and Health (ES\&H) hazards, (3) reduces facility liability, (4) potentially downgrades the sites radiological controls, and (5) reduces long-term surveillance and maintenance costs.

All above-ground buildings and structures within the TCC Facility fence will be demolished. As much demolition debris as space permits from Building 3210, Building 3211, the concrete shield wall, and the nuclear furnace piping will be placed into the Building 3210 remaining basement structure, where it will be mounded or capped and closed in place with administrative controls. Any debris that does not fit in the basement structure or demolition debris from all other buildings and structures will be managed appropriately and disposed of according to the waste management plan written for the project. It is anticipated that a certain portion of this debris will be released for disposal as sanitary waste. This will be determined by radiological surveys.

Based on final radiological survey data, Radiological Control (RadCon) will determine what radiological postings are required for any areas within the TCC Facility boundary.

\subsection{Hold PoINTS}

During closure activities, certain conditions affecting the project schedule and budget may require decisions to be made prior to continuing work.

The D\&D project team will anticipate and minimize the necessary hold points by establishing specific alternative actions. Key D\&D activities have been analyzed and potential hold points include:

- Mitigation of ES\&H hazards

- Verification of hazardous materials removal

Figure 2 shows the anticipated project flow with key decisions and hold points. Some activities may be performed concurrently or in other than specified time frames.

If at any time during the course of closure activities a hold point is reached, the U.S. Department of Energy, National Nuclear Security Administration Nevada Site Office (NNSA/NSO) will obtain consensus from the Nevada Division of Environmental Protection (NDEP) prior to beginning the next phase of closure activities. 


\section{CAU 116 AREA 25 TEST CELL C FACILITY}

Prepare plans, permits, and procedures; obtain approval to proceed.

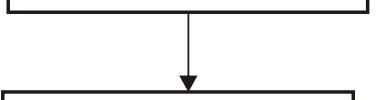

Establish control zones; mobilize equipment/labor, temporary lighting, and Hantavirus cleanup.

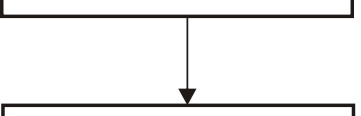

HOLD POINT \# 1

Verify safety hazards have been mitigated.
Drain fluids from equipment, piping, and reservoirs.

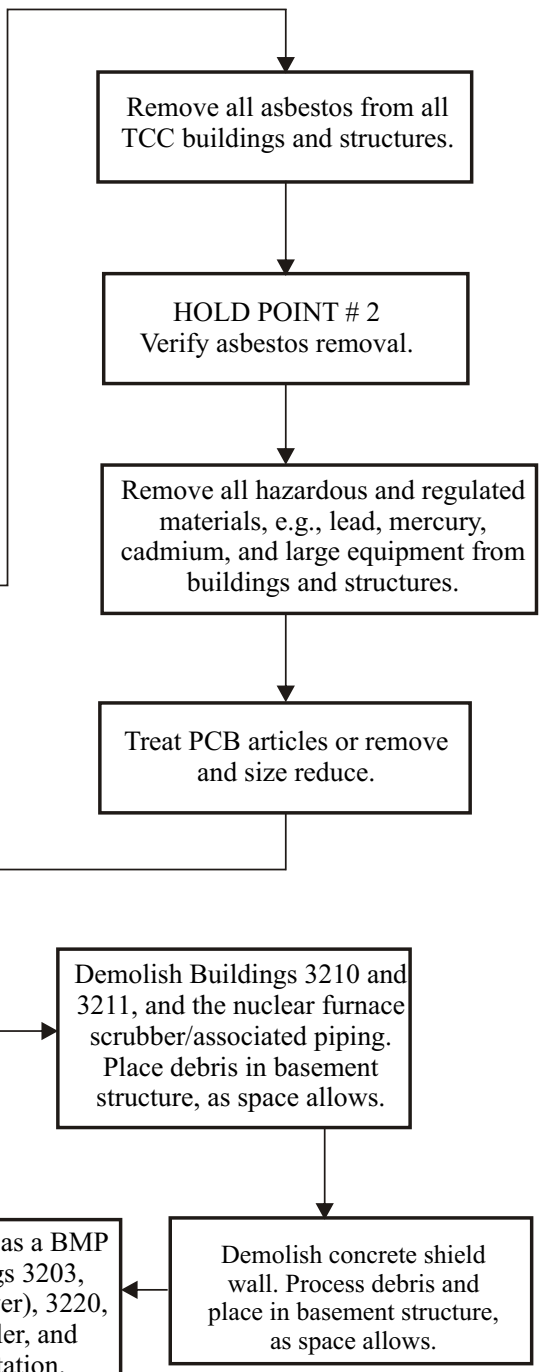

Figure 2. Project Flow Diagram and Hold Points 
In addition to the above expected hold points, work may be temporarily suspended until the issue is satisfactorily resolved if any of the following unexpected conditions occur:

- Conditions outside the scope are encountered.

- Radiological screening yields results which require an upgrade in radiological controls to continue work in specific areas.

- Elevated levels of COCs are discovered that were not originally identified as being present at the sites.

- Unexpected conditions including waste and/or contamination are encountered.

- Out-of-scope work activities are required, due to the detection of other COCs not previously identified.

- Unsafe conditions or work practices posing a threat to personnel, equipment, or the environment not originally documented in the Site-Specific Health and Safety Plan (SSHASP) are encountered.

- Other administrative or technical issues are encountered that require the preparation of a "Record of Technical Change" to the approved SAFER Plan.

\subsection{SAFER PLAN CONTENTS}

This SAFER Plan has been developed to support the closure of CAU 116 as required by the FFACO, DQO (Section 3.0), Project Organization (Appendix A), and Industrial Sites Quality Assurance Project Plan (QAPP) (U.S. Department of Energy, National Nuclear Security Administration, Nevada Operations Office [NNSA/NV], 2002), and includes the following sections:

- Section 1.0 -Introduction

- Section 2.0 -Unit Description

- Section 3.0 -Data Quality Objectives

- Section 4.0 -Field Activities and Closure Objectives

- Section 5.0 -Reports and Records Availability

- Section 6.0 -Investigation/Remediation Waste Management

- Section 7.0 -Quality Assurance/Quality Control

- Section 8.0 -References

- Appendix A -Project Organization

- Appendix B - Nevada Division of Environmental Protection Comments

- Library Distribution List 


\subsection{UNIT DESCRIPTION}

CAU 116 consists of CAS 25-41-05, Building 3210 and an attached concrete shield wall, and CAS 25-23-20, Nuclear Furnace Piping. CAU 116 is contained within the current TCC Facility fence line with buildings on a large concrete pad. The reactor pad is north of the shield wall and has a below-grade pit equipped with an instrumentation umbilical plug that mated with the test railcar.

Building 3210, constructed in 1962 of steel reinforced concrete, is approximately 1,058 square meters $\left(\mathrm{m}^{2}\right)\left(11,390\right.$ square feet $\left.\left[\mathrm{ft}^{2}\right]\right)$ in area. The roof (penthouse) consists of the Detector Room and the Neutronics Room. The ground floor consists of the Flow Control Room, High Pressure Room, Experimental Room, and Hookup Room. The basement is a footprint of the ground floor and consists of the Electronics Room, Mechanical Equipment Room, Forward Control Room, and Control Transfer Room.

Building 3211 (movable shed) is located on the reactor concrete pad on rails extending from the north side of Building 3210. The purpose of this building was to provide shelter for the test reactors, workers, and test equipment. Building 3210, constructed of steel I-beams and corrugated metal panels, is approximately $100 \mathrm{~m}^{2}\left(1,080 \mathrm{ft}^{2}\right)$.

Buildings and structures to be demolished and removed as a BMP include the dewars and associated piping; Buildings 3203 (cooling tower), 3207 (water tank), 3208 (water tower), 3211 (movable shed), 3220 (technical support center), 3230 (motor generator building), 3232 (pump house); and the NRDS \#4 Substation.

\section{$2.1 \quad$ HISTORY}

The TCC Facility was part of the NRDS, which was jointly administered by the Atomic Energy Commission and the National Aeronautics and Space Administration Space Nuclear Propulsion Office. The Preliminary Assessment detailed the CAU 116 historical operations. From 1963 to 1966, the Kiwi, Nerva, and Phoebus reactors were tested at the TCC Facility. The reactors operated by the fissioning of highly enriched uranium. Heat created by the fission process converted liquid hydrogen, which was pumped through the reactor, to hydrogen gas. This gas was then exhausted through a converging-diverging nozzle producing thrust. The reactors were mounted on railcars and fired upward with test runs ranging from several seconds to about 1 hour.

The reactors were assembled in the Reactor Maintenance, Assembly, and Disassembly (R-MAD) Facility or the Engine Maintenance, Assembly, and Disassembly (E-MAD) Facility and moved to the test cell via rail system. After firing, the test car was brought back to the disassembly bay of R-MAD or E-MAD, where the reactor was removed from the test car and disassembled.

A maze-like configuration of chemical process piping exists in Building 3210. This process piping was designed to handle the numerous gases and liquids that were used for the reactor tests. Many of the tests at TCC were part of the Kiwi, Phoebus, Nuclear Rocket Experimental, Peewee, and Nuclear Furnace series. The Transient Nuclear Test took place at TCC on January 12, 1965, on a concrete trestle northwest of the TCC reactor pad. A reactor accident occurred during the final test of Phoebus IA on June 25, 1965. During the shutting-down phase 
of the test, momentary coolant stoppage occurred. At that moment, structural damage to the reactor core resulted in the ejection of numerous pieces of damaged fuel as well as fuel particles up to $600 \mathrm{ft}$ from the reactor. This unforeseen event contaminated a large portion of the facility including Building 3210.

Reactor testing resulted in the facility being contaminated with fission products and fuel particles. Most contamination consisted of isotopes with short half-lives and has since decayed away. The remaining isotopes of primary concern include cobalt (Co)-60, cesium (Cs)-137, and strontium (Sr)-90. Additional isotopes that may be present in lesser abundance include uranium (U)-234, U-235, U-236, U-238, plutonium (Pu)-239, and Pu-240.

Between July and August of 1965, the reactor concrete pad was scrubbed repeatedly using various chemical solutions in an attempt to remove surface contamination. The porosity of unsealed concrete can inhibit effective decontamination, as was the case at Test Cell A (TCA). No one decontamination agent was universally effective; none reduced contamination levels to acceptable values on the reactor concrete pad. In order to prevent contamination of personnel, it was necessary to paint about half an acre of concrete surface. Appendix E of the Nevada Test Site (NTS) Area 25 Radiological Survey and Cleanup Project 1974-1983 presents the results of a 1978 radiological survey of various rooms within Building 3210 that, to date, have been neither validated nor interpreted. Appendix L of the same report contains radiological survey data of selected locations within TCC after decontamination activities were concluded. Although many elements in concrete can become activated by neutrons, the most prominent and longest lived of these (Co-60, europium [Eu]-152, and Eu-154) may yet be found in portions of the concrete shield wall and reactor concrete pad, due to neutron activation produced during reactor testing.

In 1969, the reactor development, engine testing, and nuclear rocket development activities were concluded at the NRDS. The TCC Facility was released for re-use in 1981. TCC was also the site in "post-Three Mile Island" studies by the Electrical Power Research Institute.

The TCC Facility has been declared excess and is in an abandoned, partially deactivated state. The facility is currently in the surveillance and maintenance program and is inspected annually according to the requirements of the Facility Decontamination and Decommissioning Program Surveillance and Maintenance Plan (NNSA/NSO, 2004a). Current conditions of the facility are documented at least annually or during facility inspections, and are provided to the surveillance and maintenance Task Manager. Figure 3 identifies the TCC Facility and the associated structures.

\subsection{SITE LOCATION}

CAU 116, Area 25 TCC Facility, is one of the five NTS sites included in the U.S. Department of Energy (DOE) D\&D Program. CAU 116 includes the following two CASs:

- CAS 25-23-20, Nuclear Furnace Piping

- CAS 25-41-05, Test Cell C Facility

Although identified as the TCC Facility, CAS 25-41-05 includes only Building 3210 and the attached concrete shield wall. CAU 116 is within the current TCC Facility fence line located northwest of the intersection of F and J Roads in Area 25 of the NTS. The site is approximately 


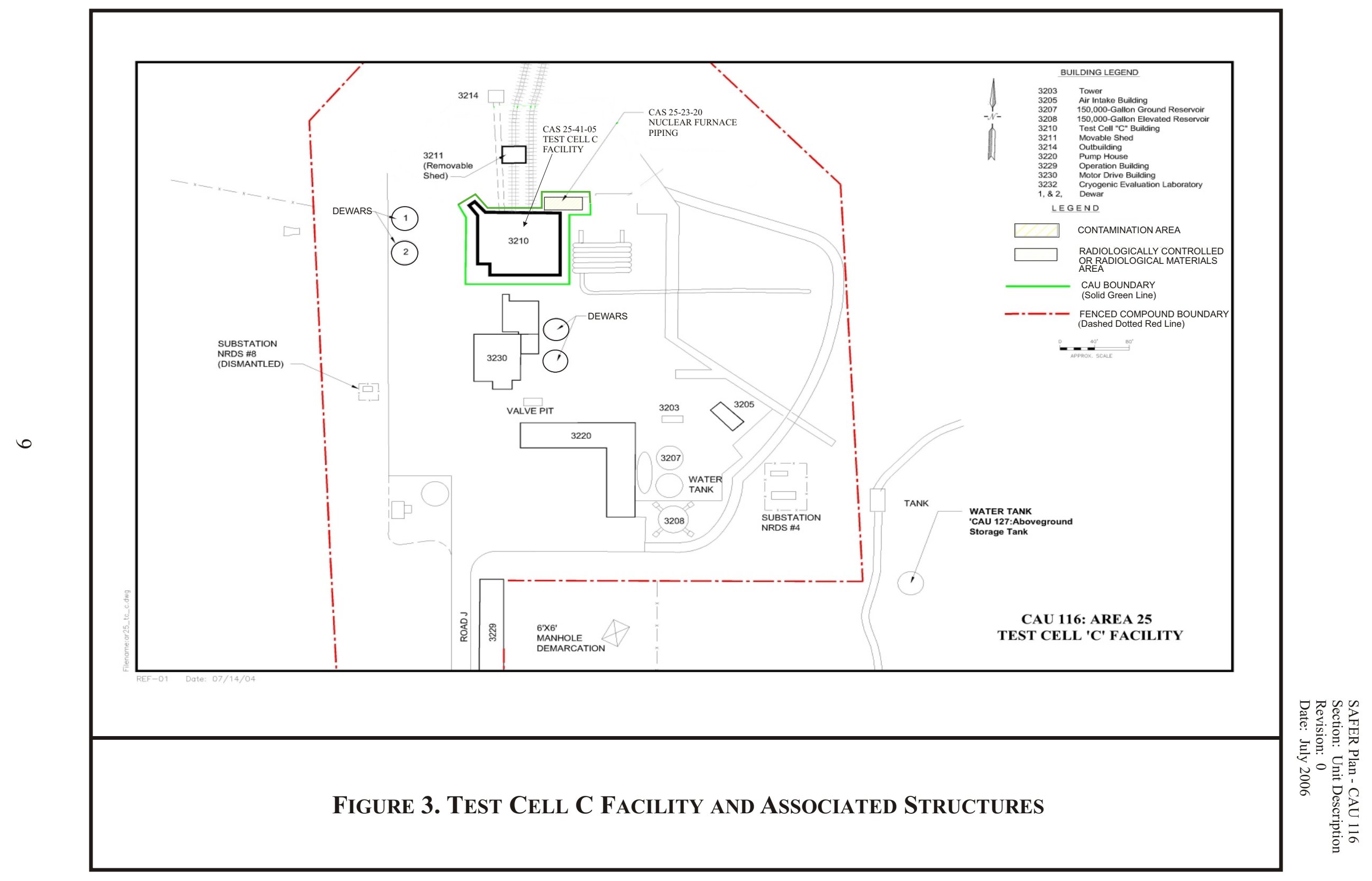


25 mile northwest of Mercury, Nevada and approximately 87 miles northwest of Las Vegas, Nevada.

\subsection{Process KnOWLEDGe}

The NRDS program is well documented. Extensive reports and documentation have been reviewed in preparation for developing this SAFER Plan. In addition to reviewing historical documents, a number of former employees were interviewed regarding standard operation activities performed at the facility. This information was evaluated and used to develop a conceptual site model (CSM) (see Section 3.1.1.1) for the types and locations of radiological and hazardous contamination within the facility. This process knowledge is further supported by:

- Site inspections

- Facility photographs

- Interviews

- Review of engineering drawings

- Analytical sample results

In addition, a former project engineer for the NRDS program worked closely with the project team providing first-hand knowledge and expertise of the facility operations systems and processes.

\subsubsection{Radioactive Contamination}

Previously identified radiologically impacted areas of the facility include the reactor concrete pad, Building 3210, Building 3211, the nuclear furnace piping, and the concrete shield wall.

Limited sections of piping and electrical conduit are embedded within the concrete walls and floors of Building 3210. Heating, ventilation, and air conditioning systems are also present in portions of Building 3210, as well as in Buildings 3220, 3230, 3232, and the NRDS \#4 Substation.

Preliminary surveys of a limited portion of the heating, ventilation, and air conditioning systems in Building 3210 detected no radiological contamination. Initial characterization surveys will verify the CSM and process knowledge, as well as provide adequate documentation for administration of radiological controls.

Surface radiological contamination exists in soil within the TCC Facility fence line. Soil remediation will not be performed as part of site closure activities.

The level and extent of radiological contamination within the TCC Facility fence will be determined by initial characterization surveys. 


\subsubsection{Hazardous and Regulated Materials}

Based on historical documentation, process knowledge, and interviews with personnel, contaminants of potential concern (COPC) are associated with the TCC Facility. The following hazardous and regulated materials are identified as, or suspected of, existing at the TCC Facility:

- Asbestos

- Lead

- Mercury

- $\quad$ PCBs

- Cadmium foil

- Freon/ethylene glycol (antifreeze)

All hazardous and regulated materials will be removed and managed as described in Section 6.2.1. Previous field screening results using an x-ray fluorescence instrument indicate that lead is present in the wall paint. Samples of paint will be collected prior to demolition to establish if lead is leachable at hazardous levels. Rolled lead is present in five shield doors. Lead wool/bricks may be present in building penetrations and other locations throughout the facility. Lead acid batteries are present in emergency lighting units.

Samples collected from silver-colored metallic foil around some Asbestos-Containing Material (ACM) insulation at TCA facility indicated hazardous levels of cadmium. Samples of similar foil material at TCC will be collected and analyzed to verify the presence of cadmium.

Freon and ethylene glycol (antifreeze) may be present in the chiller unit in Building 3210, as well as in pumps in Building 3220.

Mercury, lead, and other hazardous materials may be present in electrical components, circuit boards, batteries, switches, and instrumentation.

All items or equipment with the potential to contain mercury, lead, or other hazardous/regulated substances will be radiologically surveyed, drained of fluids, removed from the facility prior to or after demolition, and managed according to the waste management plan written for the project.

PCBs may be present in hydraulic/lubricating fluids. These fluids will be sampled and analyzed for the presence of PCBs. For management of PCB fluids, see Section 4.2.2.4. PCBs and/or lead may be found in the interior or exterior wall paints. Samples of these paints will be collected prior to demolition to identify if these COCs are present, and if so, are leachable at hazardous levels.

\subsubsection{Asbestos-Containing Material}

ACM is present as pipe/electrical cable insulation in and on buildings and structures at the TCC Facility. The presence of ACM was confirmed by laboratory analysis. Non-friable ACM is present in the mastic sealant located around penetrations on Building 3210 and transite boards are present throughout the TCC Facility. Friable ACM is present as pipe and electric cord/cable insulation, floor tiles, wall panels, and transite box panels. A minimal amount of asbestos 
insulation on electrical cables is covered with metal foil that potentially contains cadmium. Disposal of this material is discussed in Section 6.2.1. Figures 4 through 8 are examples of ACM found at TCC.

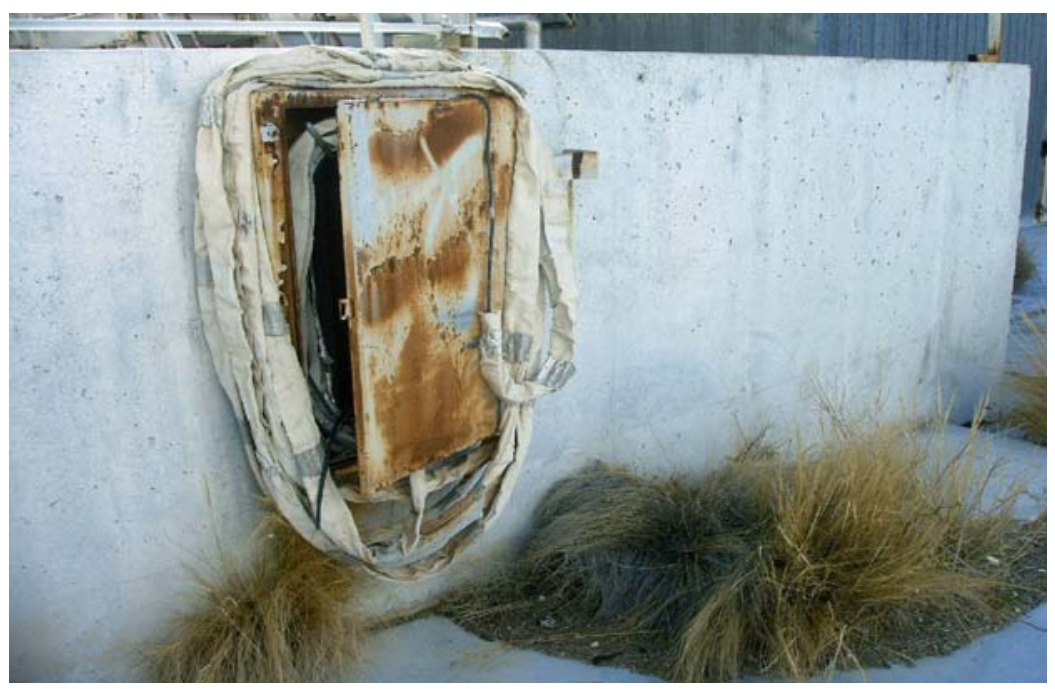

Figure 4. Asbestos-Wrapped Electric Cord

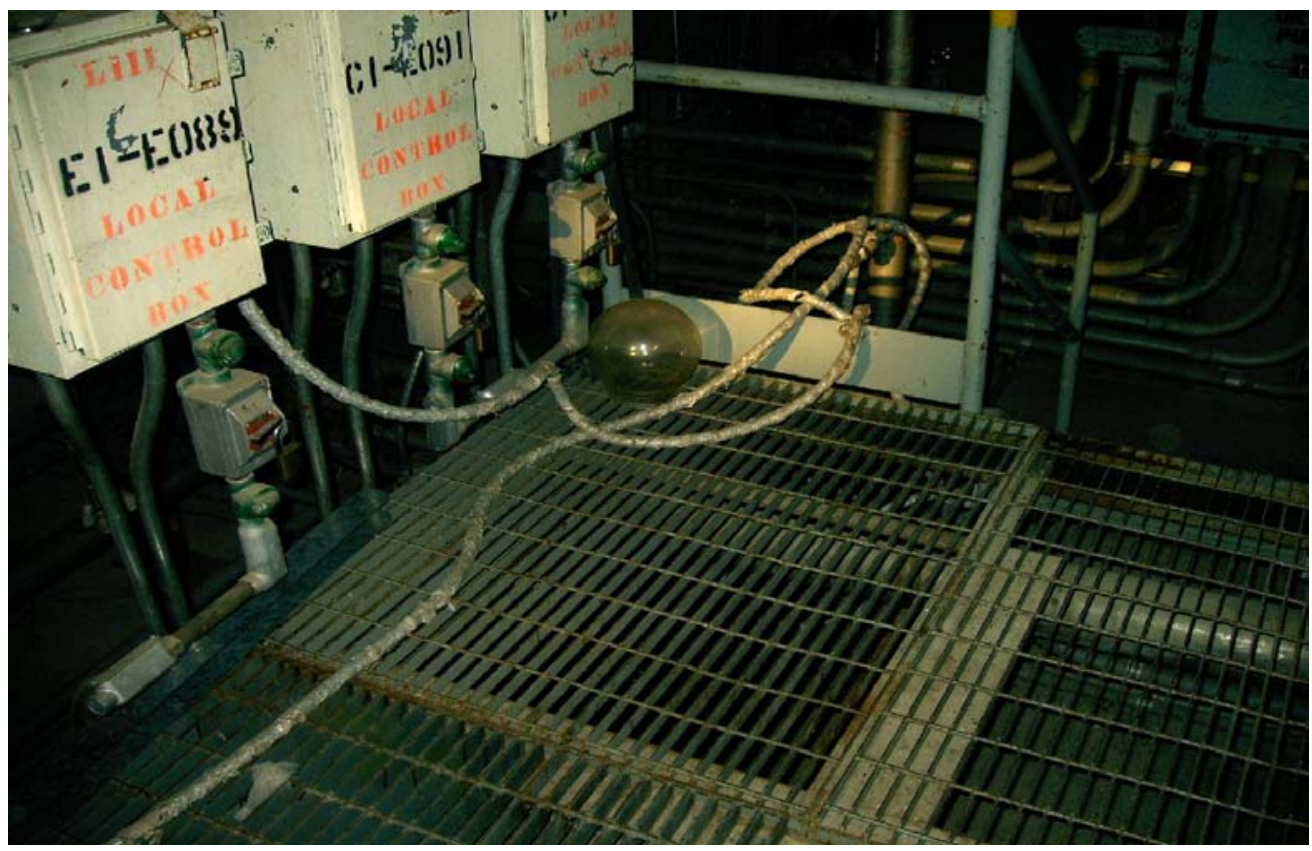

Figure 5. Asbestos-Wrapped Electrical Cable 
SAFER Plan - CAU 116

Section: Unit Description

Revision: 0

Date: July 2006

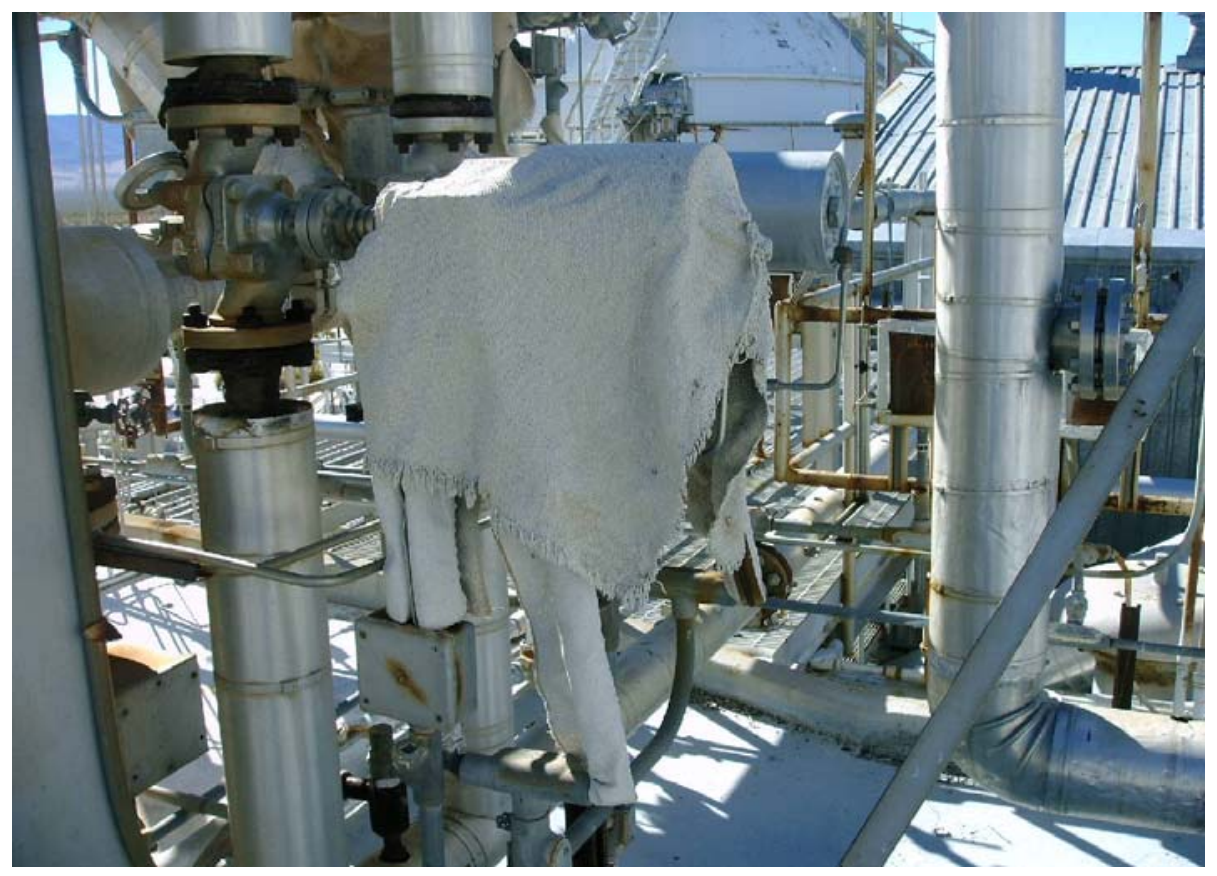

Figure 6. Asbestos-Wrapped Piping (Roof)

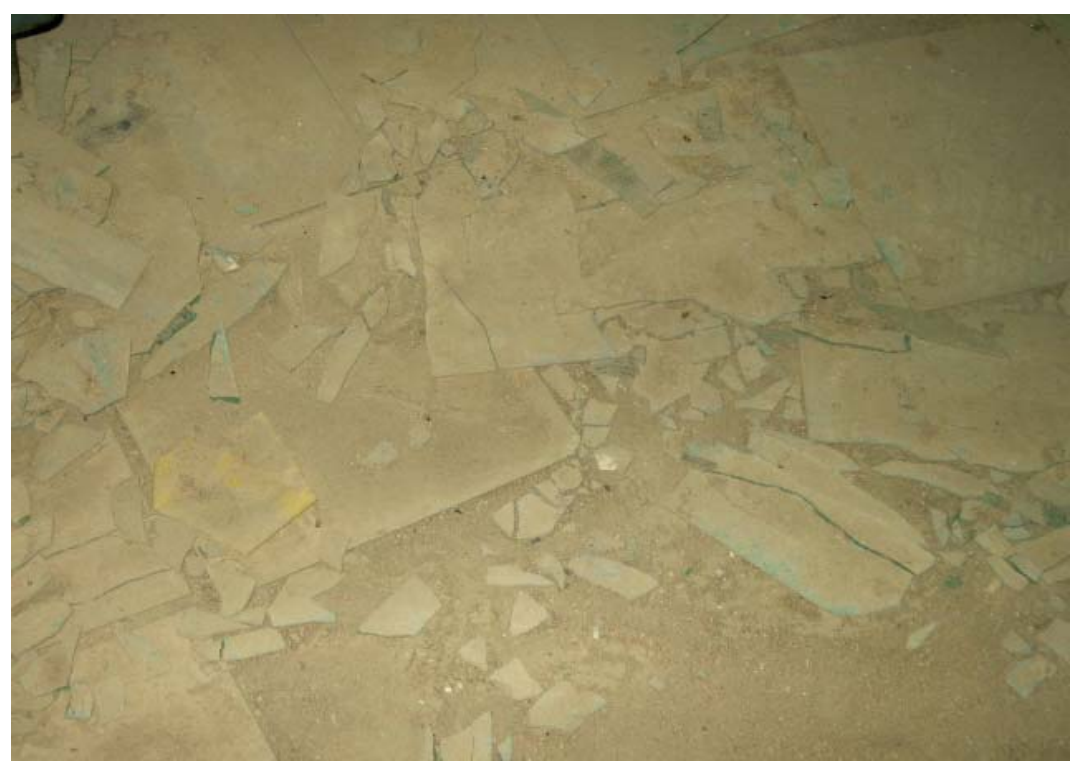

Figure 7. Asbestos Floor Tiles 


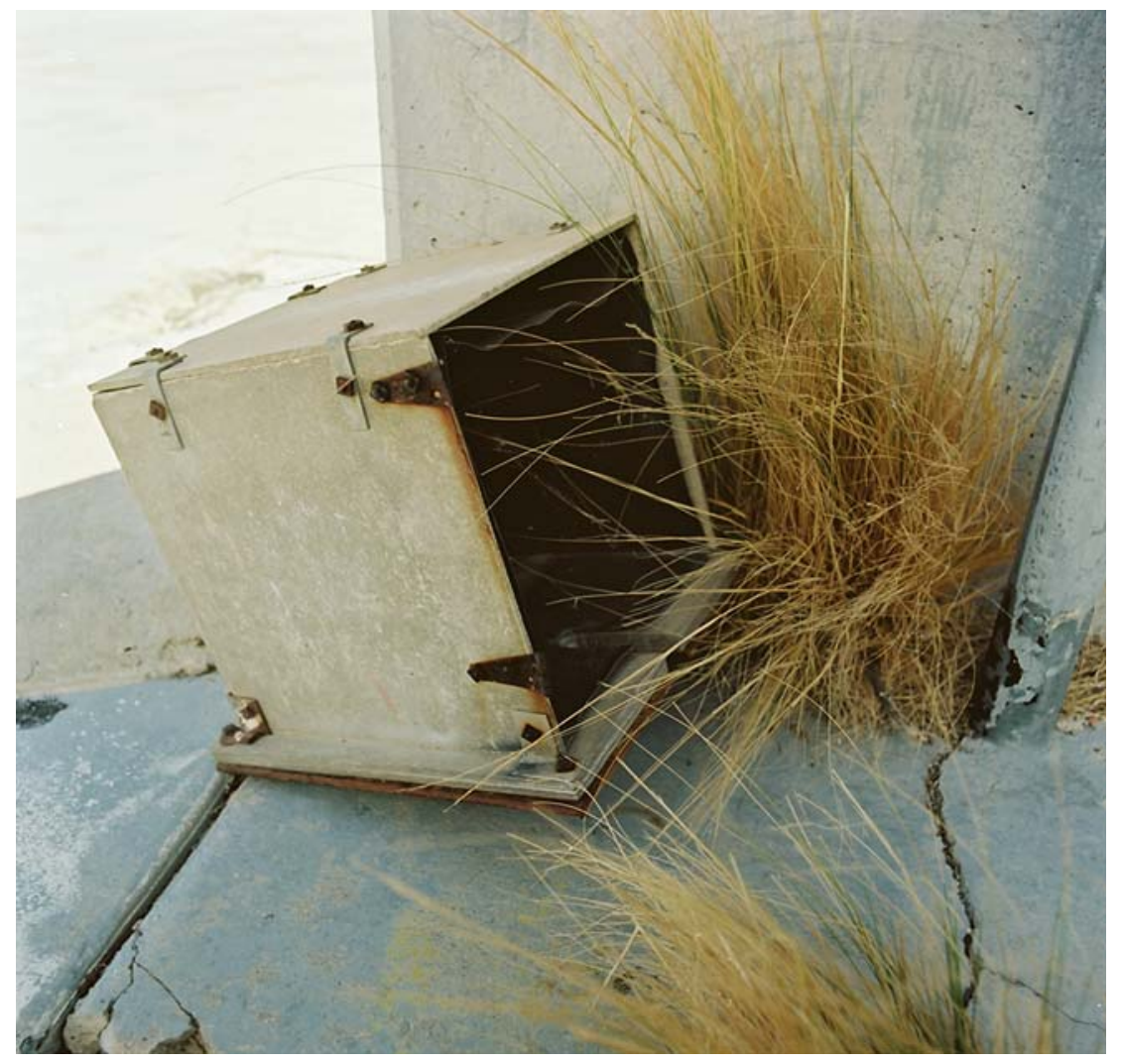

Figure 8. Asbestos Transite Panels

\subsubsection{Recyclable Materials}

Previous site inspections have confirmed the presence of solid lead throughout the facility. Potentially recyclable lead is present as rolled lead shields, bricks, and plate. Preliminary radiological surveys confirmed that the majority of lead surveyed is not radiologically impacted; however, further radiological surveys will be conducted. Rolled lead shields are encased in steel plate and make up the five shield doors in Building 3210. Lead bricks were used as shielding in building penetrations. A pallet of lead bricks, as shown in Figure 9, is located southwest of the facility, and will be radiologically surveyed and removed as a BMP. Lead wool and lead shot (if present) do not qualify for recycling and will be disposed of as hazardous waste (HW) or mixed waste (MW). Used oils that meet requirements described in Section 6.2.7.2 may be recycled on site.

\subsection{Closure STANDARDS}

The current radiological protection requirements as surface contamination limits are found in Table 2-2 of the Nevada/Yucca (NV/YMP) Mountain Project Radiological Control Manual (NNSA/NSO, 2004b) and are also displayed in Table 1 of this document. Radiological closure standards apply to all areas within the CAU 116 boundary. 


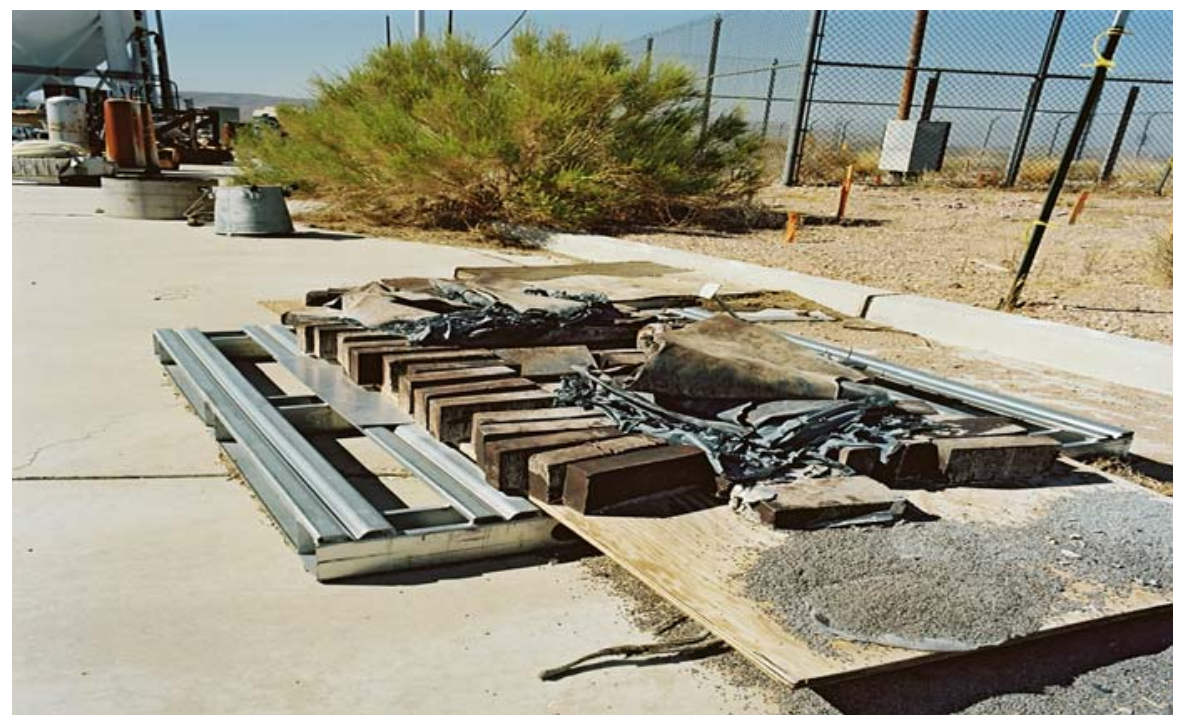

Figure 9. Lead Bricks

\subsubsection{Concrete Foundation}

Prior to demolishing the facility, all trenches and large cracks on the reactor concrete pad will be grouted or filled with concrete. After demolition activities are complete, the reactor concrete pad (Figure 10) and concrete foundations will be radiologically surveyed. Post-demolition surveys and decontamination, if necessary, of these areas will be performed as described in Section 4.2.9.

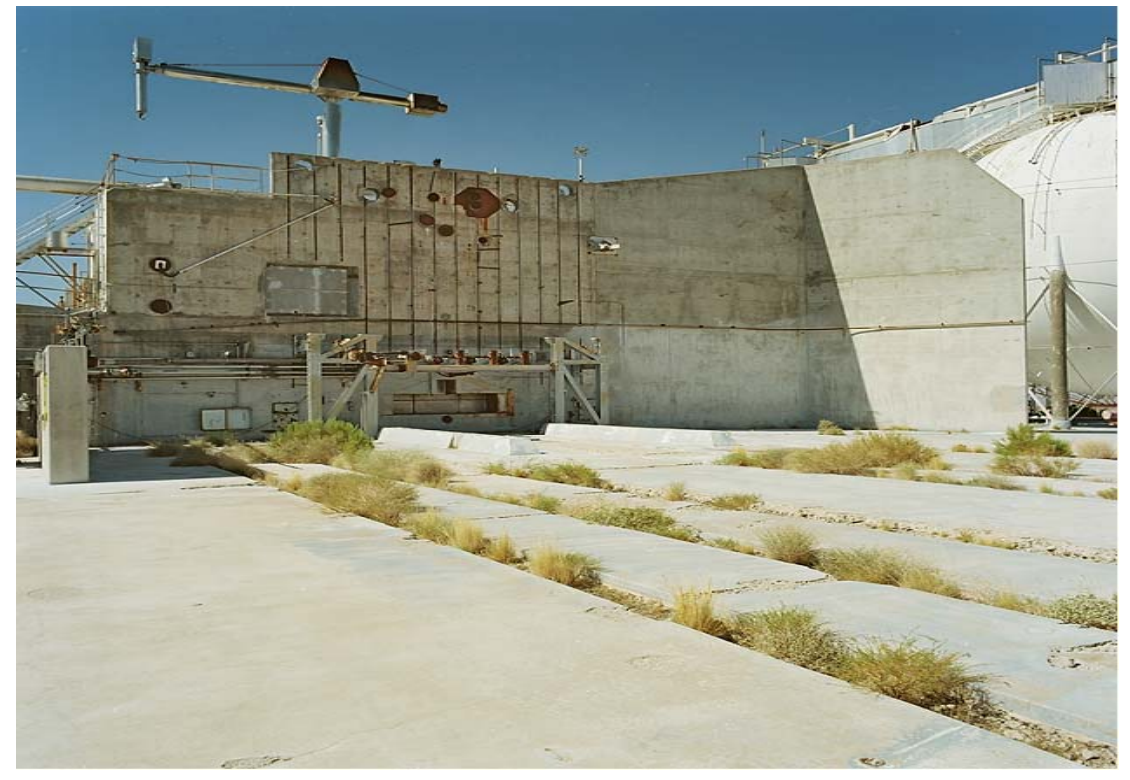

Figure 10. Reactor Concrete Pad 
Table 1. Surface Contamination Values in Disintegrations Per Minute Per 100 cm$^{2}$

\begin{tabular}{|l|c|c|c||}
\hline \multicolumn{1}{|c|}{$\begin{array}{c}\text { Nuclide } \\
\text { (Note 1) }\end{array}$} & $\begin{array}{c}\text { REMOVABLE } \\
\text { (Notes 2 \& 4) }\end{array}$ & $\begin{array}{c}\text { TOTAL } \\
\text { (FIXED + } \\
\text { REMOVABLE) } \\
\text { (Notes 2 \& 3) }\end{array}$ & $\begin{array}{c}\text { MAXIMUM } \\
\text { ALLOWABLE } \\
\text { (FIXED + } \\
\text { REMOVABLE) }\end{array}$ \\
\hline \hline U-natural, ${ }^{235} \mathrm{U},{ }^{238} \mathrm{U}$, and associated decay products & $1,000 \alpha$ & $5,000 \alpha$ & $15,000 \alpha$ \\
\hline $\begin{array}{l}\text { Transuranics, }{ }^{226} \mathrm{Ra},{ }^{228} \mathrm{Ra},{ }^{228} \mathrm{Th},{ }^{230} \mathrm{Th},{ }^{231} \mathrm{~Pa},{ }^{227} \mathrm{Ac},{ }^{125} \mathrm{I},{ }^{129} \mathrm{I} \\
\text { Th-nat, }{ }^{232} \mathrm{Th},{ }^{90} \mathrm{Sr},{ }^{223} \mathrm{Ra},{ }^{224} \mathrm{Ra},{ }^{232} \mathrm{U},{ }^{126} \mathrm{I},{ }^{131} \mathrm{I},{ }^{133} \mathrm{I}\end{array}$ & 20 & 500 & 1,500 \\
\hline $\begin{array}{l}\beta+\gamma \text { emitters }(\text { isotopes with decay modes other than } \\
\alpha-\mathrm{emission} \text { or spontaneous fission) except }{ }^{90} \mathrm{Sr} \text { and others } \\
\text { noted above (Note 5) }\end{array}$ & $1,000 \beta+\gamma$ & $5,000 \beta+\gamma$ & $15,000 \beta+\gamma$ \\
\hline Tritium and tritiated compounds (Note 6) & 10,000 & N/A & N/A \\
\hline
\end{tabular}

Source: Table 2-2, NV/YMP Radiological Control Manual (NNSA/NSO, 2004b)

$\mathrm{Ac}=$ Actinium $\quad \mathrm{I}=$ Iodine $\quad \mathrm{Pa}=$ Protactinium $\quad \mathrm{Ra}=$ Radium $\quad \mathrm{Th}=$ Thorium

Notes (Table 1):

1. The values in this table, with the exception noted in Note 5, apply to radioactive contamination deposited on, but not incorporated into, the interior or matrix of, the contaminated item. Where surface contamination by both alpha and beta/gamma-emitting nuclides exists, the limits established for alpha and beta/gamma-emitting nuclides apply independently.

2. As used in this table, disintegrations per minute means the rate of emission by radioactive material as determined by correcting the counts per minute observed by an appropriate detector for background, efficiency, and geometric factors associated with the instrumentation.

3. Levels may be averaged over $1 \mathrm{~m}^{2}$ provided the maximum surface activity in any area of 100 square centimeters $\left(\mathrm{cm}^{2}\right)$ is less than three times the value specified in Column 3 (these values are included in Column 4). For purposes of averaging, any square meter of surface shall be considered to be above the surface contamination value if:

a. From measurements of a representative number of sections it is determined that the average contamination level exceeds the applicable value; or

b. It is determined that the sum of the activity of all isolated spots or particles in any $100 \mathrm{~cm}^{2}$ area exceeds three times the applicable value from Column 3.

4. The amount of removable radioactive material per $100 \mathrm{~cm}^{2}$ of surface area should be determined by swiping the area with dry filter or soft absorbent paper, applying moderate pressure, and then assessing the amount of radioactive material on the swipe with an appropriate instrument of known efficiency.

(Note: The use of dry material may not be appropriate for tritium.)

When removable contamination is determined on objects of surface areas less than $100 \mathrm{~cm}^{2}$, the activity per unit area shall be based on the actual area, and the entire surface shall be swiped. It is not necessary to use swiping techniques to measure removable contamination levels if direct scan surveys indicate that the total surface contamination levels are within the limits for removable contamination.

5. This category of radionuclides includes mixed fission products, including the Sr-90 which is present in them. It does not apply to Sr-90 which has been separated from the other fission products or mixtures where the Sr-90 has been enriched.

6. Tritium contamination may diffuse into the volume or matrix of materials. Evaluation of surface contamination shall consider the extent to which such contamination may migrate to the surface, in order to ensure the surface contamination value provided in this table is not exceeded. Once this contamination migrates to the surface, it may be removable, not fixed; therefore, a "Total" value does not apply. 


\subsubsection{Below-Grade Piping}

Below-grade piping under the foundations of buildings or the concrete reactor pad or beyond the TCC Facility fence will not be addressed in the closure of CAU 116 . The piping will be cut flush at the surface and grouted. RadCon will determine if piping internal surveys are possible or if, due to access limitations preventing proper radiological surveys, RadCon will assume below-grade/underground piping to be internally radiologically contaminated. RadCon will determine what, if any, radiological posting is required. An example of a drain is shown in Figures 11.

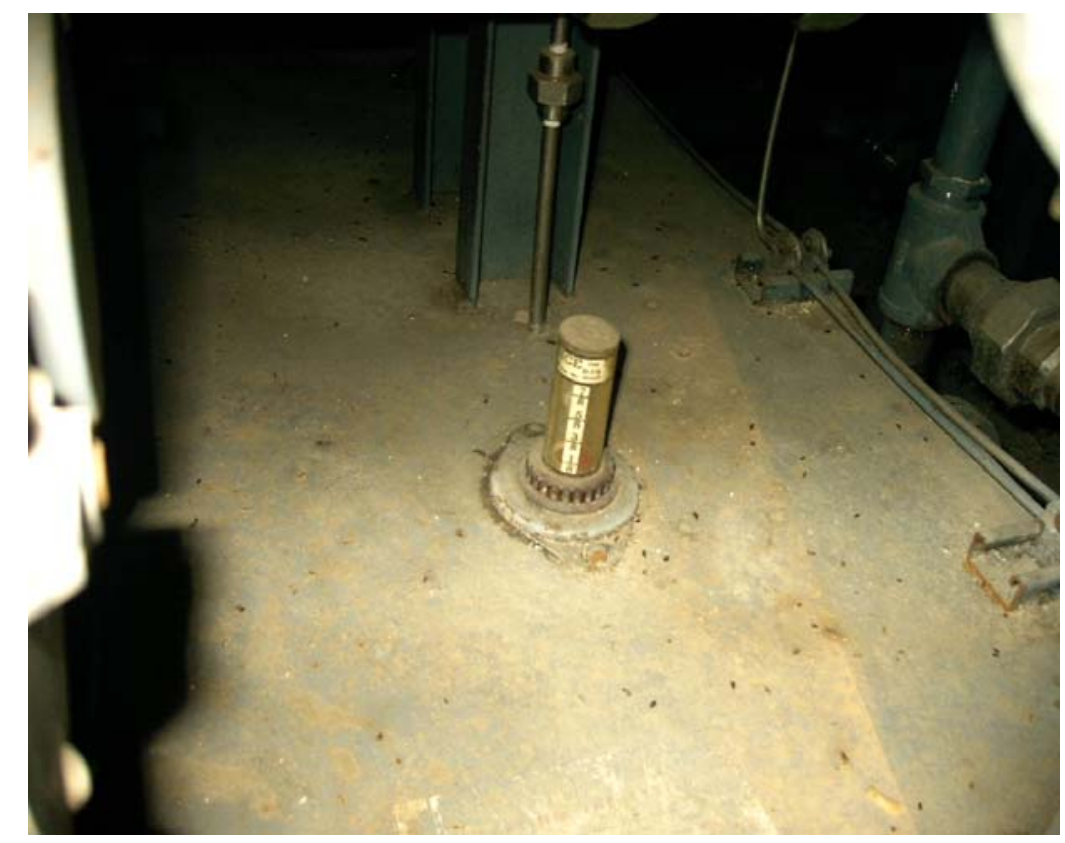

Figure 11. Below-Ground Piping and Floor Drains

Guidelines for the maximum residual radioactivity permitted to remain in the below-grade piping are derived from a fraction of the 100 milliroentgen equivalent man millirem (mrem)/year (yr) basic exposure limit. The fraction of the basic exposure limit is set at $25 \mathrm{mrem} / \mathrm{yr}$. At a minimum, the basic dose limit of $100 \mathrm{mrem} / \mathrm{yr}$ will not be exceeded under the "worst case" or "plausible-use" scenarios, consistent with the procedures and guidance provided in DOE/CH8901 (DOE, 1989). 
SAFER Plan - CAU 116

Section: Unit Description

Revision: 0

Date: July 2006

\section{THIS PAGE INTENTIONALLY LEFT BLANK}




\subsection{DATA QUALITY OBJECTIVES}

The DQO process is a seven-step strategic, systematic planning method based on the scientific method that was used to plan data collection and field investigation activities for CAU 116, Area 25 TCC. The seven steps of the DQO process presented in this report were developed in accordance with the U.S. Environmental Protection Agency (EPA) Guidance for the Data Quality Objectives Process (EPA, 2000). DQO are designed to ensure that the data collected will provide sufficient and reliable information to support the potential closure alternatives for CAU 116. Although sufficient information is available about the nature and extent of contamination at CAU 116 to suggest a closure activity, additional data is needed to verify the existing information, confirm the existence of contamination and/or waste, and affirm the closure decision.

During DQO discussions for CAU 116, data needed to resolve problem statements and decision statements were identified. Criteria for data collection and analysis were defined and agreed upon and the appropriate quality assurance (QA)/quality control (QC) required for particular data collection activities were assigned. The analytical methods and reporting limits prescribed through the DQO process and the data quality indicators (DQIs) for laboratory analysis, such as precision and accuracy requirements, are provided in more detail in Section 7.0 of this SAFER Plan.

\subsection{Summary OF DATa Quality ObJectives Analysis}

\subsubsection{State the Problem (Step 1)}

Step 1 of the DQO process describes the problem to be studied and develops a CSM to gain a sufficient understanding to define the problem.

The problem statement for CAU 116 is: "Additional information is required to verify existing information, confirm the existence of contamination and/or waste, and affirm the closure decision."

\subsubsection{Conceptual Site Model}

The CSM is used to organize and communicate information about site characteristics. It reflects the best interpretation of available information at any point in time. The CSM is based on historical documentation, personnel interviews, site process knowledge, site walk-downs, photographs, engineering drawings, field screening, and analytical results. The CSM describes the most probable scenario for current conditions at the site and defines the assumptions that are the basis for identifying an appropriate sampling strategy and data collection methods.

The CSM for CAU 116 is a contaminated facility that contains waste and contaminated materials. Waste includes equipment and materials from the nuclear rocket development era that contain hazardous constituents. CAU 116 includes all waste and contamination within the CAU boundary. Table 2 summarizes the anticipated site conditions and potential contaminants that define the CSM for CAU 116.

If additional CSM elements are identified during remediation that is outside the scope of the CSM, the situation will be reviewed and a recommendation will be made on how to proceed. In 
such cases, the NDEP and the NNSA/NSO will be notified and given the opportunity to comment on, or concur with, the recommendation.

Table 2. Summary of Conceptual Site Model for CAU 116

\begin{tabular}{|c|c|}
\hline $\begin{array}{l}\text { ANTICIPATED } \\
\text { CONTAMINANTS }\end{array}$ & Probable Location \\
\hline Radionuclides & $\begin{array}{ll}\text { - } & \text { Nuclear furnace piping } \\
\text { - } & \text { Building } 3210 \text { (roof, walls, floors, ducts, equipment) } \\
\text { - } & \text { Reactor pad } \\
\text { - } & \text { Shield wall } \\
\text { - } & \text { Possibly existing in, on, and around other buildings and } \\
& \text { structures within the TCC Facility boundary }\end{array}$ \\
\hline $\mathrm{PCBs}$ & $\begin{array}{ll}\text { - } & \text { Paint } \\
\text { - } & \text { Fluorescent light bulbs and ballasts } \\
\text { - } & \text { Hydraulic oil in equipment }\end{array}$ \\
\hline Cadmium & - $\quad$ Foil around electrical cables \\
\hline Mercury & $\begin{array}{ll}\text { - } & \text { Electrical components } \\
\text { - } & \text { Circuit boards } \\
\text { - } & \text { Switches } \\
\end{array}$ \\
\hline Lead & $\begin{array}{ll}\text { - } & \text { Circuit boards } \\
\text { - } & \text { Paint } \\
\text { - } & \text { Lead bricks } \\
\text { - } & \text { Lead wool } \\
\text { - } & \text { Shield doors }\end{array}$ \\
\hline Asbestos & $\begin{array}{ll}\text { - } & \text { Floor and ceiling tile } \\
\text { - } & \text { Piping insulation } \\
\text { - } & \text { Transite wallboard and boxes } \\
\text { - } & \text { Penetration filler (mastic) } \\
\text { - } & \text { Fire hoses } \\
\end{array}$ \\
\hline Freon/Glycol & $\begin{array}{l}\text { - } \quad \text { Chiller unit in Building } 3210 \\
\text { - } \quad \text { In pumps for the cooling towers in Building } 3220\end{array}$ \\
\hline
\end{tabular}

\subsubsection{Identify the Decisions (Step 2)}

Step 2 of the DQO process identifies the questions the study will attempt to resolve and what actions may result. The most probable closure decisions are identified below.

The Decision I statement is: "Is waste present and/or is contamination present above action levels?"

The Decision II statement is: "After removal of hazardous/regulated waste, demolition of the buildings, and removal of transferable radioactive contamination, does the risk to personnel and the environment justify the removal of the remaining radiological contamination?" 


\subsubsection{Identify the Inputs to the Decisions (Step 3)}

Step 3 of the DQO process identifies the information needed, the sources of information, and sampling and analysis methods that can meet the data requirements.

\subsubsection{Information Needs}

In order to confirm the CSM and the nature and extent of contamination, data must be collected and analyzed using the following criteria:

- Data will be collected from locations most likely to contain contamination (judgmental sampling approach).

- The analytical suite selected will be adequate to detect contaminants present in the samples.

\subsubsection{Sources of Information}

Information needed to satisfy the decisions will be generated by collecting samples and conducting radiological surveys. Information generated will be in the form of:

\section{Quantitative Data}

Quantitative data measure the quantity or amount of a characteristic or component. These data require the highest level of QA/QC in collection and measurement systems because the intended use of the data is to resolve primary decisions and/or verify closure standards have been met. Laboratory analytical data are generally considered quantitative.

A judgmental (biased) sampling approach will be used. Samples will be collected from locations likely to be contaminated, using appropriate sampling methods. The locations likely to be contaminated are summarized in Table 2. Samples will be submitted to analytical laboratories meeting the quality criteria stipulated in the Industrial Sites QAPP (NNSA/NV, 2002). Only validated data from analytical laboratories will be used to support DQO decisions. Sample collection and handling activities will follow standard procedures.

\section{Semiquantitative Data}

Semiquantitative data indirectly measure the quantity or amount of a characteristic or component. Inferences are drawn about the quantity or amount of a characteristic or component, because a correlation has been shown to exist between the indirect measurement and the results from a quantitative measurement. The $\mathrm{QA} / \mathrm{QC}$ requirements on semiquantitative collection and measurement systems are high, but may not be as rigorous as for a quantitative measurement system. Semiquantitative data contribute to decision-making but are not used alone to resolve primary decisions. Field-screening data are generally considered semiquantitative. The data are often used to guide investigations toward quantitative data collection.

Field screening activities will be conducted for alpha and beta/gamma radiation/contamination. A handheld radiological survey instrument or other method will be used, based on the possibility that portions of buildings, the reactor pad, piping, and equipment are radiologically contaminated. These field screening techniques will provide semiquantitative data that can be used to guide verification sampling and waste management activities. Core samples of materials 
may then be collected for In-Situ Object Counting System (ISOCS) analysis based on these results.

\section{Qualitative Data}

Qualitative data identify or describe the characteristics or components of the site. The QA/QC requirements are the least rigorous on data collection methods and measurement systems. The intended use of the data is for information purposes, to refine CSMs, and to guide investigations rather than resolve primary decisions. This measurement of quality is typically assigned to historical information and data where QA/QC may be highly variable or not known. Professional judgment is often used to generate qualitative data.

\subsubsection{Define the Study Boundaries (Step 4)}

Step 4 of the DQO process defines the target population of interest, specifies the spatial boundaries and time constraints of that population pertinent for decision-making, and determines practical constraints on data collection.

\subsubsection{Population of Interest}

The population of interest to resolve the decisions includes the materials that are impacted by a contaminant above the action level.

\subsubsection{Spatial Boundaries}

The spatial boundaries include all above-ground buildings and structures within the TCC Facility fence.

\subsubsection{Time Constraints}

The study data should be relevant with the length of time allowed for by the SAFER process under the FFACO agreement (FFACO, 1996). Data will be collected at times that meet the security and safety constraints of the NTS and at times when weather conditions allow adequate site access and safe working conditions. The final SAFER Plan will be submitted by September 2006. Closure activities are currently scheduled to begin in Fiscal Year 2007.

\subsubsection{Practical Constraints}

Other constraints that may affect the ability to collect data include the following:

- Approval of SAFER Plan and DQO

- Equipment access and availability at the NTS

- Issue/award of demolition subcontract

- Acceptance of waste disposal pathways

- Other unsafe working conditions 


\subsubsection{Develop a Decision Rule (Step 5)}

Step 5 of the DQO process develops a decision rule ("If..., then...") statement that defines the conditions under which possible alternative actions will be chosen. In this step, the statistical parameters that characterize the population of interest are specified, the action levels are specified, and the measurement and analysis limits are confirmed capable of detecting action levels.

\subsubsection{Population Parameters}

Each sample result within the population of interest defined in Step 4 will be compared to the action levels to determine the appropriate resolution to the decisions.

\subsubsection{Decision Rules}

The decision rules for Decision I and Decision II are as follows.

\section{Decision I}

- If waste or contamination above action levels is present, then the practicality of its removal will be determined.

- If no waste or contamination above action levels is present, then the material in question will be considered sanitary waste.

\section{Decision II}

- All hazardous/regulated waste and transferable radiological contamination will be removed and disposed.

- Any radiological contamination that is not practical to remove based on the risk assessment (e.g., activated concrete) will be closed in place.

\subsubsection{Action Levels}

Action levels for chemical contaminants are defined as the EPA Region 9 risk-based preliminary remediation goals for chemical constituents in industrial soils (EPA, 2004). Action levels for radiological contaminants are based on the National Council on Radiation Protection (NCRP) Report No.129, recommended screening limits for construction, commercial, industrial land-use scenarios (NCRP, 1999) scaled to $25 \mathrm{mrem} / \mathrm{yr}$ dose constraint (Murphy, 2004), and the generic guidelines for residual concentration of radionuclides in DOE Order 5400.5 (DOE, 1993). The radiological action level for solid media will be defined as the unrestricted-release criteria defined in the NV/YMP Radiological Control Manual (NNSA/NSO, 2004b) Table 4-2.

Remaining radiological contamination, per Decision II of the decision rules, will be posted per the NV/YMP Radiological Control Manual (NNSA/NSO, 2004b).

\subsubsection{Measurement and Analysis Sensitivity}

The measurement and analysis methods listed in the Industrial Sites QAPP (NNSA/NV, 2002) are capable of measuring analyte concentrations at or below the corresponding action levels for each constituent. 


\subsubsection{Specify Tolerable Limits on Decision Errors (Step 6)}

Step 6 of the DQO process specifies performance criteria for the decision rules. Setting tolerable limits on decision errors requires the planning team to weigh the relative effects of threat to human health and the environment, expenditure of resources, and the consequences of an incorrect decision. This section provides an assessment of the possible outcomes of DQO decisions and the impact of those outcomes if the decisions are in error.

EPA's DQO guidelines state that if a judgmental sampling approach is used, quantitative statements about data quality will be limited to measurement error (EPA, 2000). Measurement error is influenced by imperfections in the measurement and analysis system. Random and systematic measurement errors are introduced in the measurement process during physical sample collection, sample handling, sample preparation, sample analysis, and data reduction. If measurement errors are not controlled, they may lead to errors in making the DQO decisions.

In general, confidence in DQO decisions based on judgmental sampling results will be established qualitatively by:

- Developing CSMs.

- Testing the validity of the CSMs based on investigation results.

- Evaluating the quality of the data based on DQI parameters.

\subsubsection{Decision Errors}

The baseline condition (i.e., null hypothesis) and alternative condition for Decision I are:

- Baseline condition: Waste or contamination above action levels is present.

- Alternative condition: Waste or contamination is not present.

The baseline condition (i.e., null hypothesis) and alternative condition for Decision II are:

- Baseline condition: It is practical to remove all waste and/or contamination.

- Alternative condition: It is not practical to remove all waste and/or contamination.

\section{False Negative}

A false negative decision error would mean deciding contamination is not present when it actually is (Decision I), or deciding it is not feasible to remove waste or contamination when it actually is feasible to do so (Decision II). In both cases the potential consequence is an increased risk to human health and environment. The false negative decision error is controlled by meeting these criteria:

- Having a high degree of confidence that the sample locations selected will identify contamination if present anywhere within the CAS. To satisfy this criterion, samples will be collected in areas most likely to be contaminated. This was considered during development of the CSM. Table 2 summarizes these locations. Systematic radiological surveys will be conducted of the facility. In addition, the sample size determination for COC containing paint will be made using statistics based on EPA guidance for lead and PCBs. 
- Having a high degree of confidence that the analyses conducted will be sufficient to detect any contamination present in the samples. To satisfy this criterion, the DQI of sensitivity will be assessed for all analytical results, to ensure that all sample analyses had detection limits that were less than or equal to the corresponding action level.

- Having a high degree of confidence that the dataset is of sufficient quality. To satisfy this criterion, the data will be assessed against the DQIs of precision, accuracy, comparability, and completeness. The appropriate QC samples will be collected as defined in the Industrial Sites QAPP (NNSA/NV, 2002).

\section{False Positive}

The false positive decision error would mean deciding contamination is present when it actually is not (Decision I) or deciding it is practical to remove waste or contamination when it actually is not practical (Decision II). In both cases the result would be increased costs. False positive errors for Decision I are typically attributed to laboratory and/or sampling errors that could cause cross-contamination. To control against cross-contamination, decontamination of sampling equipment will be conducted according to established and approved procedures. Only clean sample containers will be used. False positive errors for Decision II will be avoided by presenting and reviewing plans for removal of waste with the NNSA/NSO and the NDEP to help mitigate impractical remediation activities.

\subsubsection{Optimize the Design (Step 7)}

Step 7 of the DQO process provides the general approach for obtaining the information necessary to resolve the decisions. A judgmental sampling scheme will be implemented to select sample locations and evaluate analytical results. EPA's DQO guidelines state that a judgmental sampling approach can be used when there is sufficient information on the contamination sources and history to develop a valid CSM and to select specific sampling locations (EPA, 2000). This design is used to confirm the existence of contamination at specific locations and provide information about specific areas of the site. Sample locations for judgmental sampling will be determined based on process knowledge and previously acquired data. Table 3 summarizes the locations where samples will be collected and the analyses to be performed. Although additional areas of probable hazardous/regulated waste are identified in Table 2, samples will not be collected from these areas. Instead, the existence of waste will be verified by visual observations, and the materials will be disposed appropriately. In addition, radiological contamination will be identified by extensive, systematic, radiological surveys and ISOCS analysis of core samples. 
Table 3. Sample Analysis Requirements

\begin{tabular}{|c|c|c|}
\hline PARAMETER & ANALYTICAL METHOD & LOCATION \\
\hline PCBs & $8082^{\mathrm{a}}$ & Hydraulic oil in equipment \\
\hline TCLP PCBs & $1311 / 8082$ & Paint \\
\hline TCLP Lead & $1311 / 6010 \mathrm{~B}^{\mathrm{a}}$ & Paint \\
\hline TCLP Cadmium & $1311 / 6010 \mathrm{~B}^{\mathrm{a}}$ & Foil around piping and conduit \\
\hline Radionuclides & $\begin{array}{l}\text { Field Screening and ISOCS } \\
\text { analysis of core samples }\end{array}$ & 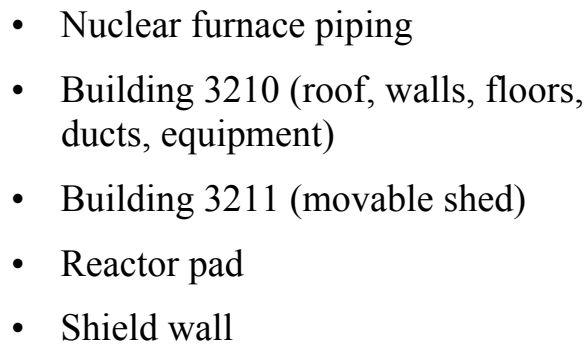 \\
\hline
\end{tabular}

${ }^{\mathrm{a}}$ Test Methods for Evaluating Solid Waste, $3^{\text {rd }}$ Edition, Parts 1-4, SW-846 (EPA, 1996)

$\mathrm{PCB}=$ polychlorinated biphenyls

TCLP $=$ Toxicity Characteristic Leaching Procedure

\subsection{Results of The Data Quality ObJectives Analysis}

\subsubsection{Action Level Determination and Basis}

Action levels for chemicals are defined as the EPA Region 9 risk-based preliminary remediation goals for chemical constituents in industrial soils (EPA, 2004). Action levels for radiological contaminants are based on the NCRP Report No. 129-recommended screening limits for construction, commercial, industrial land-use scenarios (NCRP, 1999) scaled to $25 \mathrm{mrem} / \mathrm{yr}$ dose constraint (Murphy, 2004), and the generic guidelines for residual concentration of radionuclides in DOE Order 5400.5 (DOE, 1993). The radiological action level for solid media will be defined as the unrestricted release criteria defined in the NV/YMP Radiological Control Manual (NNSA/NSO, 2004b) Table 4-2. Remaining radiological contamination, per Decision II of the decision rules, will be posted per the NV/YMP Radiological Control Manual (NNSA/NSO, 2004b).

\subsubsection{Hypothesis Test}

Only valid data from radiological surveys and laboratory analytical results will be used to determine if contamination is present. The null hypothesis for Decision I is that waste and/or contamination above action levels is present. The two types of decision errors are false negative and false positive. A false negative decision error would occur if contamination is determined not to be present above the action levels when it actually is, increasing risk to human health and the environment. A false positive decision error would occur if contamination is determined to be present above the action levels when it actually is not, resulting in increased costs for unneeded remediation.

\subsubsection{Statistical Model}

The sample size determination for COC containing paint will be made using statistics based on EPA guidance for lead and PCBs. For all other sampling, individual sample results, rather than 
an average concentration, will be used to compare to action levels. Statistical models will not apply.

\subsubsection{Design Description/Option}

Biased (judgmental) samples will be collected as summarized in Table 3. These locations were chosen based on process knowledge of the site. Systematic radiological surveys will be conducted to identify radiological contamination.

\subsubsection{Conceptual Site Model}

The CSM is presented in Section 3.1.1.1 and summarized in Table 2. 
SAFER Plan - CAU 116

Section: Data Quality Objectives

Revision: 0

Date: July 2006

THIS PAGE INTENTIONALLY LEFT BLANK 


\subsection{FIELD ACTIVITIES AND CLOSURE OBJECTIVES}

This section provides the framework and rationale for characterization, removal, closure verification, waste disposal, and site restoration. The SAFER Plan process is discussed in detail in the following subsections.

Prior to beginning the corrective action investigation and site closure fieldwork, the following activities will be (or have been) completed:

- Collect aerial photographs of the facility.

- Review preliminary assessment materials and process knowledge.

- Obtain additional data as needed to support project planning.

- Prepare a "National Environmental Policy Act Checklist."

- Prepare a SSHASP.

- Prepare an NNSA/NSO Real Estate/Operations Permit.

- Prepare a sampling and analysis plan (SAP).

Closure of CAU 116 will be accomplished by completing the following activities:

- Mitigate ES\&H hazards.

- Perform initial characterization surveys.

- Remove all hazardous and/or regulated materials.

- Fill all trenches and large cracks on the reactor pad with grout or similar material.

- Demolish Building 3210 (to grade), the concrete shield wall, and the nuclear furnace piping and place as much demolition debris as space allows in the remaining basement structure.

- As a BMP demolish and remove all other buildings and structures within the TCC Facility fence including the dewars and associated piping; Buildings 3203, 3207, 3208 (water tower), 3211 (moveable shed), 3220, 3230, 3232; and the NRDS \#4 Substation. Place as much demolition debris in the basement structure, as space allows.

- Mound or cap the basement structure.

- Remove transferable contamination from concrete surfaces and the reactor concrete pad.

- Perform final radiological surveys to determine the radiological controls required for areas within the TCC Facility boundary.

\subsection{Contaminants of Potential Concern}

Based on analytical results and process knowledge, the following COC (Table 4) are likely to be present.

- $\mathrm{ACM}$

- PCBs 
- Radionuclides

- Resource Conservation and Recovery Act (RCRA) metals (e.g., lead, mercury, and cadmium)

Table 4. Contaminants of Concern

\begin{tabular}{|c|c|c|c|c|c|c|c|c|c|}
\hline \multirow[b]{2}{*}{ CAS \# } & \multirow{2}{*}{$\begin{array}{c}\text { CAS } \\
\text { DESCRIPTION }\end{array}$} & \multicolumn{6}{|c|}{ CONTAMINANTS OF CONCERN } & \multirow{2}{*}{$\begin{array}{c}\text { IMPACTED/ } \\
\text { NON-IMPACTED } \\
\text { DEMOLITION } \\
\text { DEBRIS } \\
\end{array}$} & \multirow{2}{*}{$\begin{array}{c}\text { CONTAMINANT/ } \\
\text { WASTE DESCRIPTION }\end{array}$} \\
\hline & & ACM & LEAD & PCBs & Cadmium & MERCURY & RAD & & \\
\hline 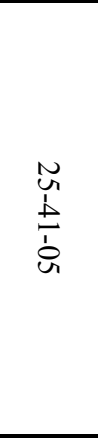 & $\begin{array}{l}\text { Building } 3210 \\
\text { (including the } \\
\text { attached } \\
\text { concrete shield } \\
\text { wall) }\end{array}$ & Yes & Yes & Yes & Yes & Yes & Yes & Yes & $\begin{array}{l}\text { The facility contains asbestos } \\
\text { as insulation/tiles/ } \\
\text { fire hoses/wall panels/ } \\
\text { roofing sealant; solid lead, } \\
\text { and lead in batteries and } \\
\text { circuit board solder; } \\
\text { PCB-containing lubricants } \\
\text { and paint, light ballasts, } \\
\text { mercury vapor bulbs and } \\
\text { switches, cadmium foil, and } \\
\text { radiologically impacted } \\
\text { concrete. }\end{array}$ \\
\hline 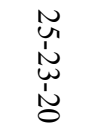 & $\begin{array}{l}\text { Nuclear } \\
\text { Furnace } \\
\text { Piping }\end{array}$ & Yes & No & No & No & No & Yes & Yes & Nuclear furnace piping. \\
\hline
\end{tabular}

\subsubsection{Asbestos-Containing Material}

Sampling at TCC has been conducted on suspected ACM. Potential friable asbestos in the form of wall panels (in Building 3230), insulation on piping, conduit, electrical cords/cables, and an unspecified volume of non-friable ACM in the form of mastic roofing sealant were included in this sampling.

The majority of piping at TCC does not contain ACM insulation. ACM insulation is found primarily on electrical cables, conduit, and some pipe elbows. Some ACM-insulated electrical cables are also found to be covered with silver-colored metal foil. Sampling of similar foil at TCA showed it contained hazardous levels of cadmium. Samples of this foil at TCC will be collected to verify the presence of cadmium.

Mastic roofing sealant is located around roof and wall penetrations and cracks on Building 3210 . Similar material was previously analyzed at TCA, where it was determined to contain non-friable $\mathrm{ACM}$ at greater than 1 percent, as well as being radiologically impacted. Sampling and analysis of this material at TCC will be performed prior to demolition activities to verify this material is radiologically impacted ACM (asbestiform low-level waste [LLW]). All ACM materials will be removed by certified asbestos workers, according to the Management and Operations (M\&O) contractor, DOE, state, and federal regulations.

\subsubsection{Polychlorinated Biphenyls}

Samples will be collected at TCC to determine the extent of PCBs in paint covering the walls and/or floors of buildings. Samples of lubricating/hydraulic fluids will also be collected to 
determine if PCBs are present. Drained fluids will be containerized in preparation for selection of a disposal pathway. If PCBs are present, the PCB articles, objects, piping, and/or containers that contained the drained fluid will be treated as discussed in Section 4.2.2.4.

\subsubsection{Radionuclides}

The types and quantities of radiological contamination, generated by reactor testing conducted at TCC, have been well documented. A considerable amount of information on the operation of the facility is presented in published literature and historical records. Available information includes the types of reactors, type of fuel used, power levels, run times, effluent, and results of past decontamination efforts and radiological surveys. Interviews with former workers, captured in preliminary assessment information combined with information gathered during recent site inspections with a former NRDS project engineer, have provided information on how facility operations were conducted and the known, or suspected, COPCs existing at the TCC Facility.

ISOCS surveys conducted at TCA, where similar reactor testing took place, identified the following radiological radioactive COCs: Co-60, Cs-137, Eu-152, Eu-154, and niobium-94 at quantities greater than the minimum detectable activity. Detailed ISOCS analysis of the TCC shield wall and reactor pad will be conducted to verify the presence of the isotopes and their concentrations.

Radiological COC of primary concern at TCC are Sr-90, Co-60, Cs-137, Eu-152, Eu-154, $\mathrm{U}-234, \mathrm{U}-235$, and $\mathrm{Pu}-239$. Co-60 contamination is the result of the neutron activation, produced during reactor testing, of the stainless steel and concrete structures. Pu-239 is produced by the neutron activation of the relatively small fraction of U-238 contained in the reactor fuel. Based upon its relative contribution to the total activity, $\mathrm{Pu}-239$ is not expected to impact waste classifications or work processes. U-234 and U-235, from ejected fuel/fallout, contribute approximately 99 percent of the total alpha activity.

\subsubsection{Resource Conservation and Recovery Act Metals}

Unrecyclable lead, mercury, and cadmium are known or suspected to be present within the TCC facility. These metals fall under RCRA (EPA, 2001) regulations.

\subsubsection{Recyclable Lead}

Solid lead removed from TCC may be reused or recycled within the DOE complex depending on the current demand for regulated lead.

Lead was used as shielding material throughout the facility. Lead bricks were installed in the shield wall penetrations of Building 3210 and known to exist in minimal quantities in other buildings and various locations (flair stack area, rubble piles, etc.) throughout the TCC fenced area. Five shield doors present in Building 3210 contain rolled lead. In addition, non-radiologically impacted lead-acid batteries are present throughout the facility in non-operational emergency lighting units. All hazardous and recyclable lead will be radiologically surveyed, removed, managed, recycled, re-used, or disposed of as described in Section 4.2.2.2. 


\subsubsection{Mercury}

Mercury is present in fluorescent light bulbs. All fluorescent light bulbs will be removed prior to demolition and managed as universal waste per Title 40 Code of Federal Regulations (CFR) 273.13) (EPA, 2003a) and the CAU 116 Waste Management Plan (WMP). For details regarding the management of this waste stream, refer to Section 6.2.7.4. Possible mercury containing items (e.g., mercury switches, thermostats, circuit boards, and instrumentation) as shown in Figure 13 will be identified, removed, and disposed of according to the WMP. For details regarding the management of this waste stream, refer to Section 6.2.1. No other mercury-containing items have been observed in the TCC Facility. All possible mercury-containing items will be removed prior to demolition and managed appropriately.

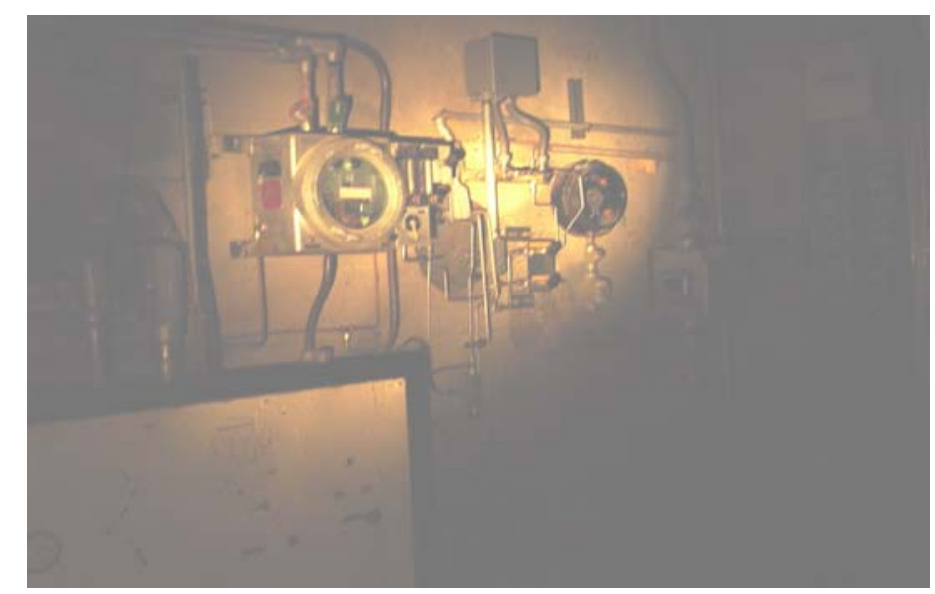

Figure 122. Representative Mercury Containing Item

\subsubsection{Other Hazardous Constituents}

All HW or items containing hazardous materials will be removed, managed, and disposed of according to the WMP. If additional hazardous materials are encountered that have not been previously identified, they will be removed, managed, and disposed of appropriately.

\subsection{REMEDIATION}

The following remediation activities are required to close CAU 116:

- Provide ES\&H analysis to determine appropriate personal protective equipment.

- Install hazard postings as appropriate.

- Verify all power lines are de-energized and disconnected.

- Install portable lighting units as appropriate.

- Identify and clean rodent infestation areas (Hantavirus hazard).

- Alert all personnel of biological hazards (e.g., bats, snakes) located in Building 3210.

- Alert all personnel of owls nesting in Building 3211 (safe displacement).

- Perform initial characterization radiological surveys. 
- Remove hazardous and regulated materials:

- $\operatorname{ACM}$ (e.g., piping and conduit insulation, wall panels, transite boxes)

- Cadmium foil

- $\quad$ Lead (e.g., rolled lead shields, bricks, wool)

- Electrical components containing hazardous materials

- Radiologically impacted materials

- PCB liquids and PCB articles (if present)

- Freon and/or ethylene glycol (antifreeze) potentially in the chiller unit in Building 3210 and in pumps in Building 3220

- Mercury (electrical components, fluorescent light bulbs)

- Drain fluids and gases from system piping and equipment.

- Fill all trenches and large cracks on the reactor pad with grout or similar material.

- Remove large pieces of equipment and reuse or ship to an approved NTS disposal site.

- Demolish Building 3210 (to grade), the concrete shield wall, and the nuclear furnace piping; place as much of this demolition debris as space allows into the remaining basement structure.

- As a BMP, demolish and remove all other buildings and structures within the TCC Facility fence including the dewars and associated piping; Buildings 3203, 3207, 3208 (water tower), 3211 (moveable shed), 3220, 3230, 3232; and the NRDS \#4 Substation.

- Place as much demolition debris as space allows into the Building 3210 basement structure.

- Remove transferable contamination from the reactor pad and concrete foundations, if necessary.

- Perform final release and confirmatory radiological surveys to determine the radiological controls and use restrictions required for areas within the TCC Facility boundary.

The activities required to close CAU 116 are detailed in the following sections.

\subsubsection{Mitigate Safety Hazards}

Initial activities will mitigate existing hazardous conditions to provide a safe and efficient work environment at the facility. As a corrective action in providing safe illumination, portable lighting will be installed at building entrances and locations throughout the buildings. Rodent droppings (Hantavirus potential) will be cleaned and bagged according to the appropriate regulatory requirements. Access control and personnel monitoring policies will be developed and administered during all D\&D activities. The absence of voltage in power lines entering and throughout the building will be verified prior to the start of demolition activities.

\subsubsection{Hazardous and Regulated Waste Removal}

\subsubsection{Asbestos-Containing Material Abatement}

Site inspections and laboratory analysis have confirmed that ACM is present in the form of wall panels, pipe and electrical cord/cable insulation, mastic sealant, ceiling and floor tiles, and transite boxes. Throughout the facility, pipes were insulated with ACM. In addition, asbestos 
insulation exists on electrical cables wrapped with silver-colored metallic foil. ACM pipe insulation is also located in limited amounts throughout the surrounding buildings. Mastic sealant is present around penetrations on the roof and some walls of Building 3210 .

As noted in Section 2.1, the reactor incident that occurred during the final test of Phoebus IA on June 25,1965 , resulted in contamination of a large portion of the facility. The event dispersed fuel particles onto the roof of Building 3210, where contamination attached to the mastic roofing sealant. This contamination, which was not addressed during previous decontamination activities, may also be present on/within asbestos insulation on piping and conduit, and under roof paint. Initial characterization surveys will include the mastic roofing material and ACM pipe insulation.

All ACM will be removed and packaged for disposal by appropriately trained and qualified asbestos workers. This work will be accomplished according to the M\&O Company Directives (CDs), site procedures, local, state, and federal regulations. Management and disposal of ACM is located in Section 6.2.2 through Section 6.2.4.

\subsubsection{Lead}

Lead used as shielding material is present throughout the TCC Facility. The five shield doors are filled with rolled lead. Potentially recyclable lead bricks and non-recyclable lead wool may be present in wall penetrations. All practical attempts shall be made to remove solid lead prior to demolition.

If lead cannot be removed prior to demolition (i.e., embedded or too heavy to remove due to equipment access limits), the lead and its immediate surrounding area shall be marked with high visibility paint. During or after demolition, the sections containing the lead will be segregated from the building debris, be removed, and managed according to the WMP. Approval from the ER Task Manager and RadCon will be required in this event.

Lead is present as solder on numerous circuit boards of electrical equipment located in all of the buildings. Circuit boards will be removed prior to demolition and be managed and disposed of according to the WMP.

Lead wool and/or shot will be placed into drums after removal and managed as MW or HW, depending on location. Lead wool and/or shot may be assumed to be radiologically impacted due to the inability to gather proper radiological surveys on these materials. For management of this waste stream, see Section 6.2.7.1.

Field screening results indicate that the TCC Facility contains lead-based paint. Prior to demolition activities, paint samples will be collected according to an approved SAP to verify lead leachability is below hazardous levels.

\subsubsection{Polychlorinated Biphenyls}

Analytical results confirm that PCB-based paint is present on the walls and floors of the facility. There are no plans to remove paint from floors and walls prior to demolition. The PCB-based paint is classified as "Applied Dried Paints" per 40 CFR 761.62 (b)(i) (EPA, 2003e). Samples 
will be collected according to the SAP to identify PCB concentrations. For details regarding the management of this waste stream, refer to Section 6.2.6.

Fluorescent light ballasts that contain PCBs will be removed and disposed as non-leaking PCB ballasts per 40 CFR 761.60 (b)(2)(ii) (EPA, 2003d). For details regarding the management of this waste stream, refer to Section 6.2.6.

Samples of the hydraulic fluids will be collected and analyzed for PCBs. If determined to contain PCBs, hydraulic fluid from systems will be drained, drummed, and managed as Toxic Substances Control Act (TSCA)-regulated PCB liquid. If PCBs are not present, the fluids may be recycled.

\subsubsection{PCB Articles (i.e., PCB-impacted Equipment)}

Hydraulic systems that contain liquids (e.g., piping, distribution lines, articles, and reservoirs) will have the contents drained or pumped into appropriate containers, sampled, and analyzed for any regulated substances. If sample analysis confirms PCBs are present, all impacted equipment, reservoirs, piping, etc., will be decontaminated using approved methods specified in 40 CFR 761.79(c) (EPA, 2003f). These methods include rinsing with, or soaking in, a performance-based organic decontamination fluid, such as diesel fuel or other approved performance-based organic decontamination fluids referenced in 40 CFR 761.79(c) (EPA, 2003f). Once the impacted materials meet the decontamination standard referenced in 40 CFR 761.79(b)(3)(i)(A) (EPA, 2003f), the piping/equipment may be disposed of as sanitary waste.

Performance-based organic decontamination fluids will be sampled after use and disposed of according to 40 CFR 761.79(g), (EPA, 2003f). If stained on concrete, the PCB concrete surface will be aggressively removed and samples of concrete collected, to verify cleanup is complete. PCB concrete decontamination waste is classified as "Non-liquid building demolition debris" and may be disposed of as "PCB bulk product waste" per Section 6.2.6.

\subsubsection{Draining Lubricants/Fluids from Equipment}

All equipment and piping will be drained of lubricants/fluids prior to disposal or cutting. All lubricants/fluids will be sampled according to the SAP for hazardous/radiological constituents. Sample analytical results will determine if the lubricants/fluids will be reused, recycled, or managed, and disposed of according to the WMP.

\subsubsection{Removal of Radiologically Impacted Items or Materials}

Preliminary radiological surveys indicate that minimal contaminated surfaces or equipment remain in the interior of the facility. The majority of equipment that will be removed from the building interior is expected to be released for disposal as sanitary waste. Some items, due to size and/or weight, may require removal after demolition activities begin when freer access of demolition equipment to these items is gained. Approval from the ER Task Manager and RadCon will be required in this event. The potential for cross-contamination (i.e., the spread of contamination to uncontaminated items or debris) will be addressed by RadCon prior to demolition activities. 
Some items (e.g., pipe internals or equipment) may have inaccessible surfaces preventing proper radiological surveys. The ER HP will determine the feasibility of characterizing this material by its liquid content radiological analysis or by the use of ISOCS.

\subsubsection{Initial Characterization Surveys}

Initial characterization surveys will be performed by RadCon Technicians (RCTs) to identify radiologically impacted areas or items/materials that require removal or decontamination prior to demolition. Initial characterization surveys will identify both transferable and fixed surface contamination, areas that are activated, as well as areas or items with elevated (greater than background) beta and/or gamma dose rates. Section 4.2.6.1 and Section 4.2.6.2 provide the survey methodology.

Previous radiological surveys identified the following areas as radiologically impacted: ACM roofing sealant, the concrete shield wall, the stainless steel pipes on the roofs and exterior of Building 3210, a limited amount of pipe insulation, the reactor concrete pad, and the concrete foundation supporting the ACM-insulated pipes on the northeast side of Building 3210. Based on radiological survey data at the TCA facility where similar reactor testing took place, it is anticipated that portions of the Building 3210 concrete (in addition to the shield wall) will be activated. Initial characterization surveys will identify the presence and extent of building surfaces that are radiologically impacted. Core samples of the reactor pad, the concrete shield wall, and any other locations required by the SAP will be collected and analyzed by ISOCS to determine the concentrations and ratios of isotopes present. All radiological surveys and analytical data will be appropriately documented.

After demolition activities are complete, characterization survey data will be used to calculate a total radiological activity and concentration remaining in the filled basement structure.

\subsubsection{Survey Methods}

All radiological surveys will be completed according to the survey plan written for the project and appropriately documented according to the NV/YMP Radiological Control Manual (NNSA/NSO, 2004b) and M\&O procedures.

\subsubsection{Surface Contamination}

Surface contamination is contamination deposited on, but not incorporated into the interior or matrix of the contaminated item.

Areas and materials will be classified as "surface contaminated" or "not surface contaminated," based on the NV/YMP Radiological Control Manual (NNSA/NSO, 2004b), Table 2-2, "Surface Contamination Values," (Table 1 in this document). Sanitary waste will meet the Area 9 U10c Landfill requirements for surface contamination. Releasing solid items or materials to uncontrolled areas will meet the NV/YMP Radiological Control Manual (NNSA/NSO, 2004b), Table 4-2, "Allowable Total Residual Surface Contamination Values." Items that have inaccessible surfaces preventing proper radiological surveys that are, have been, or may have been, in a contamination area, high contamination area, or airborne radioactivity area will be 
evaluated by RadCon to allow release, or to be controlled, or to be disposed of as radioactive material.

For large area wipes and fixed contamination surveys, the NE Technology Electra portable count rate meter combined with the DP series Dual Scintillation probe or equivalent survey instrument will be used. The Electra, when used with the DP series probe, allows for the simultaneous survey of alpha and beta contamination displaying activity results in counts per minute. The instrument can be set to display alpha-only activity, beta-only activity, or to read and display both combined alpha-beta activities. For large area direct contamination monitoring, RadCon may dictate the use of other appropriate instrumentation.

For transferable contamination surveys, swipe samples will be collected. Swipe samples will be counted using instrumentation deemed appropriate by RadCon. Contamination survey results will be appropriately documented.

All radiological survey instruments will be used according to $\mathrm{M} \& \mathrm{O}$ operating procedures. Surveys will be performed according to survey plans written for the project or in accordance with approved procedures.

\subsubsection{Volumetric Contamination}

Volumetric contamination is contamination incorporated into the interior or matrix of the material. Concentration is typically reported as activity per unit volume (e.g., $\mu \mathrm{Ci} / \mathrm{cc}$ ). Volumetric materials (e.g., soil, wood, or activated concrete) require sampling and laboratory analysis or use of the ISOCS or equivalent system for determining isotopic concentrations.

For the purpose of verifying compliance with the Area 9 U10c Industrial Landfill Permit radioactive concentration limits, the ISOCS may be used.

All analytical data (e.g., ISOCS analysis and core sample analysis results) will be presented in the CR.

\subsubsection{Building Demolition}

Previous radiological surveys indicated the majority of the facility is not radiologically impacted with transferable contamination above the levels specified in Table 1. However, a radiological airborne hazard may be created during the destructive demolition (concrete being rubblized) of structures containing activated concrete or surfaces with fixed radiological contamination. RadCon will assess the extent of this potential at TCC and determine the necessary controls.

After removing equipment and regulated or hazardous materials, all buildings and structures within the TCC Facility fence will be demolished to grade level. A combination of traditional demolition and controlled explosive demolition techniques will be used. Controlled explosive demolition may be employed in areas where traditional demolition methods are not feasible or efficient, or where Project Management deems appropriate.

The debris from Building 3210 will be used to fill the remaining basement structure. Space permitting, as much demolition debris as possible from Building 3211, the concrete shield wall, 
and the nuclear furnace piping will also be placed into the basement structure. (Some of this piping may qualify for disposal as sanitary waste.) Other non-hazardous items, equipment, or debris may also be placed in the basement structure, if space allows. After filling, the basement structure will be mounded or capped to control rain runoff. Items (e.g., equipment and large piping) that are determined not to fit in the basement structure due to size or lack of space will be managed appropriately and disposed of according to the WMP at an approved NTS disposal site. All other building and structure demolition debris, whether sanitary or LLW, not placed in the basement structure will be managed appropriately and disposed of according to the WMP at an approved NTS disposal site.

The void space (wide trench) under two motor/generators in Building 3230 will be filled with native, clean fill or concrete/grout after the one remaining motor/generator is removed. After demolition, any additional existing trenches, voids or pits in the concrete slabs, and any void spaces beneath the dewars, will be filled to grade with clean fill, or concrete/grout.

\subsubsection{Post-Demolition Surveys}

After demolition activities are complete (e.g., removal of demolition debris), the capped basement structure, the reactor pad, and the remaining concrete foundations within the TCC Facility boundary will be radiologically surveyed. Surveys will be completed using survey instruments and methods described in Section 4.2.6.1 and Section 4.2.6.2.

Any open pipes or drains will be sealed to contain and immobilize any internal contamination. Contaminated drains will be appropriately posted to communicate known or potential radiological hazards. Drain systems or below-ground pipes that cannot be properly surveyed and for which there is no process knowledge regarding their use, will be assumed to be internally contaminated and be posted accordingly.

RCTs will perform radiological surveys according to the radiological survey plan written for the project, following applicable RadCon and M\&O procedures. Review of radiological survey data is the responsibility of $\mathrm{M} \& \mathrm{O}$ RadCon supervision.

\subsubsection{Decontamination of Radiologically-Impacted Surfaces}

If post-demolition radiological surveys indicate the presence of transferable radiological contamination on the reactor concrete pad or concrete foundations that exceed the limits specified in Table 1, attempts will be made to decontaminate the area(s) preferably using non-aggressive methods (e.g., high-efficiency particulate air vacuums, masslinn wipes, wet wipes, scrub brushes with soapy water or bio-degradable cleaning solutions/solvents, or strippable paint). Verification surveys will be completed to confirm that transferable contamination does not exceed Table 1 limits. If non-aggressive decontamination efforts are unsuccessful in removing transferable contamination levels to below Table 1 limits, the ER Task Manager and ER HP will determine the appropriate, more aggressive decontamination method required to reduce the transferable contamination to acceptable levels. Aggressive decontamination methods may include the use of the following but is not limited to needle guns, scabblers, chippers, grit blasters, or jackhammers. 
Fixed contamination and activated concrete may become transferable contamination through the use of aggressive decontamination methods; therefore, this potential shall be assessed prior to aggressive decontamination methods being employed for the removal of transferable contamination. It is anticipated that areas containing only fixed contamination and activated concrete will be left in place and, if required, posted appropriately by RadCon.

\subsubsection{Posting}

It is planned that the current TCC Facility fence will be left in place to control site access. No additional fencing will be required. The site will be radiologically posted per the NV/YMP Radiological Control Manual (NNSA/NSO, 2004b).

NV/YMP Radiological Control Manual (NNSA/NSO, 2004b) Chapter 2, Part 3, Sub-Part 231, Paragraph 11(b)(3) states:

\footnotetext{
"Areas may be excepted from the Radioactive Materials Area (RMA) posting requirements of 10 CFR 835.603(g) when: The radioactive material of concern consists solely of structures or installed components that have been activated (i.e., such as being exposed to neutron radiation or particles produced in an accelerator)."
}

Note: This posting exception does not apply to areas containing fixed radiological contamination.

A use restriction will be required for any areas within the CAU boundary that have been radiologically posted. In addition, the basement structure, containing the encapsulated debris, will be posted to communicate radiological content and bulk product PCBs found within. Post-closure monitoring and posting requirements will be defined in the CR.

\subsection{VERIFICATION}

Radiological surveys for total and transferable contamination are required to verify the effectiveness of decontamination activities on the remaining concrete surfaces within the TCC Facility fence. No additional analytical data or analysis is required to verify that the remaining concrete surfaces have been decontaminated to acceptable levels to achieve closure. (See Section 4.2.9.)

Initial site inspections indicate that chemical COCs have not impacted the building foundations and pads that will remain after closure of the TCC Facility. The Building 3210 basement foundation is the only exception to this due to small stained areas of concrete beneath equipment that will be removed prior to demolition. The basement and the demolition debris will be considered low level PCB bulk product waste. Therefore, the small stained areas present on the foundation will be considered the same type of waste and will not be remediated, and verification samples will not be required. If during site closure additional areas of suspected chemical COCs are discovered, additional remediation activities will be proposed to NNSA/NSO and NDEP.

\subsection{Closure}

Specific activities required to close CAU 116 are described in Section 4.2. Hold points and special conditions that may be outside the initial project assumptions of this SAFER Plan may impact the requirements for closure. General closure activities include:

- Site setup and field preparation activities (including mitigation of safety hazards). 
- Initial characterization surveys.

- Pre-demolition activities including removal of hazardous/regulated and/or radiologically impacted substances or materials.

- Filling all trenches and large cracks on the reactor pad with grout or similar material.

- Demolition of Building 3210, the concrete shield wall, the nuclear furnace piping, and placement of as much of this demolition debris as space allows in the remaining basement structure.

- Demolition and removal of, as a BMP, all other buildings and structures within the CAU boundary (e.g., the dewars and associated piping; Buildings 3203, 3207, 3208 [water tower], 3211 [movable shed], 3220, 3230, 3232; and the NRDS \#4 Substation).

- Placement of as much demolition debris as space permits into the Building 3210 basement structure.

- Mound or cap the basement structure after filling with debris.

- Remove transferable radioactive contamination, preferably using non-aggressive methods (e.g., high-efficiency particulate air vacuums, masslinn wipes, wet wipes, scrub brushes with soapy water or bio-degradable cleaning solutions/solvents, or strippable paint), from concrete surfaces within the TCC Facility fence.

- Post-demolition radiological surveys.

- Installing final site postings and use restrictions, as necessary.

- Project closeout including preparation and submittal of a CR to the NNSA and NDEP for approval.

Upon approval of the CR from NDEP, the NNSA/NSO will request that CAU 116 be promoted to Appendix IV of the FFACO, "Closed Corrective Action Units."

\subsection{DURATION}

Closure activities at the TCC facility are scheduled to be completed during Fiscal Year 2007. The fieldwork portion of the project will require approximately 1 year to complete. The schedule will require modifications if conditions exist that are outside the assumptions on which this SAFER Plan was developed. All attempts will be made to conduct work in a manner that maximizes safety and efficiencies (i.e., some activities will occur concurrently), and minimizes the amount of personnel required to complete closure activities. Table 5 presents the proposed project schedule. 
Table 5. Project Schedule

\begin{tabular}{|c|c|c|}
\hline Project Phases & $\begin{array}{l}\text { APPROXIMATE } \\
\text { DURATION }\end{array}$ & ACtivities \\
\hline Planning & 78 weeks & $\begin{array}{l}\text { SAFER Plan, demolition plan, training, readiness review, } \\
\text { work package development, radiological surveys. }\end{array}$ \\
\hline Site Setup & 2 weeks & Trailers, temporary lighting, equipment setup, postings. \\
\hline Liquid and Gas Removal & 5 weeks & $\begin{array}{l}\text { Drain all pipe fluids and gasses, drain equipment reservoirs } \\
\text { and lubricating fluids. }\end{array}$ \\
\hline $\begin{array}{l}\text { Hazardous and } \\
\text { Regulated Material/ } \\
\text { Equipment Removal }\end{array}$ & 24 weeks & $\begin{array}{l}\text { Asbestos abatement, RCRA metals, PCBs, freon/ethylene glycol } \\
\text { (antifreeze) and large equipment removal, cut and treat PCB articles }\end{array}$ \\
\hline Demolition & 7 weeks & $\begin{array}{l}\text { Demolition of Building 3210, concrete shield wall, Building 3211, Nuclear } \\
\text { Furnace Piping; place debris in basement structure. }\end{array}$ \\
\hline $\begin{array}{l}\text { Demolition of dewars } \\
\text { and all other structures } \\
\text { within the TCC Facility } \\
\text { fence as BMP }\end{array}$ & 22 weeks & $\begin{array}{l}\text { As a BMP, demolish and remove the dewars and all other buildings and } \\
\text { structures within the TCC Facility fence. Transport debris to appropriate } \\
\text { NTS disposal site. }\end{array}$ \\
\hline LLW Shipping/Disposal & 1 week & $\begin{array}{l}\text { All LLW not placed in the basement will be loaded and transported to an } \\
\text { appropriate NTS LLW landfill. }\end{array}$ \\
\hline Final Decontamination & 2 weeks & $\begin{array}{l}\text { Remove transferable contamination from reactor pad, concrete foundations, } \\
\text { and decontaminate equipment. }\end{array}$ \\
\hline $\begin{array}{l}\text { Final Radiological } \\
\text { Surveys }\end{array}$ & 1 week & Document radiation and contamination levels, install postings. \\
\hline Close-out & 12 weeks & Final radiological surveys, project files, and project close-out. \\
\hline SAFER CR & 36 weeks & CR preparation and approval. \\
\hline
\end{tabular}


SAFER Plan - CAU 116

Section: Field Activities

Revision: 0

Date: July 2006

\section{THIS PAGE INTENTIONALLY LEFT BLANK}




\subsection{REPORTS AND RECORDS AVAILABILITY}

Prior to beginning closure activities, several work control processes must be implemented. This document is available in the DOE Public Reading Rooms located in Las Vegas, Nevada, and Carson City, Nevada, or by contacting the appropriate DOE Project Manager. The NDEP maintains the official Administrative Record for all activities conducted under the auspices of the FFACO. These documents will be onsite and referred to as necessary to perform work in a safe and orderly manner.

\subsection{Field Management Plan}

A field Management Plan (FMP) will be prepared prior to beginning closure activities. The FMP will outline the schedule for the project, and will indicate how safety will be integrated into the work management and how the field activities will be accomplished. In addition, the FMP will identify the responsible parties for each aspect of the project and will indicate how decisions will be made. Copies of the FMP will be available at the work site and will be on file in the M\&O ER offices in Mercury, Nevada.

\subsection{National Environmental Policy Act Checklist}

A "National Environmental Policy Act Checklist" and any subsequent documentation will be completed prior to beginning closure activities. In 2000, a cultural resource evaluation was completed by the Desert Research Institute documenting the historical significance of the TCC Facility. In the event that closure activities impact areas and wildlife adjacent to the TCC Facility, follow-up surveys will be performed. Copies of the checklist and support documentation will be kept on file at the site and in the M\&O ER offices in Mercury, Nevada.

\subsection{DAILY FIELD REPORTS}

A detailed Daily Field Report will be compiled to document activities that have been completed, identify any issues, and report how each issue was, or is being, resolved. This report will be provided to the ER Task Manager who will communicate the progress of the field activities to the NNSA/NSO Task Manager.

The NNSA/NSO Task Manager will act as a liaison to the NDEP oversight staff member and provide any requested additional field information. Copies of the reports and support documentation will be filed in the M\&O ER offices in Mercury, Nevada.

\subsection{RADIOLOGICAL SURVEY REPORTS}

Radiological Survey Reports, log entries, or other documentation deemed appropriate by RadCon, will be completed for radiological surveys performed during closure of the TCC Facility. A few examples and reasons for performing radiological surveys include:

- Material being removed from contamination areas or waste containers being shipped offsite.

- Equipment used inside contamination areas.

- Characterization surveys (i.e., waste, contaminated surfaces)

- Verification surveys 
- Free release of items or equipment

- Periodic surveys of personnel:

- When a potential exposure to hot particles (fuel fragments) exists.

- While workers are in, and upon exiting, a contamination area or high-contamination area.

- Final surveys (post-demolition)

Radiological surveys will be appropriately conducted and documented by RCTs. Typical survey information includes fixed and transferable contamination levels, exposure rates, and any other information deemed appropriate by the survey generator. All radiological survey data will be reviewed by M\&O RadCon Supervision. Copies of the Radiological Survey Reports and support documentation will be filed in the M\&O ER offices in Mercury, Nevada. Final verification surveys will be included in the CR.

\subsection{CLOSURE REPORT}

Upon completion of the approved closure activities, a CR will be prepared and submitted to NDEP for approval. The CR will include all the sections required by the approved FFACO outline for the CR. In general, the CR will include the following sections:

- Introduction (purpose and scope)

- Closure activities (description of corrective action activities, deviation from the SAFER Plan as approved, corrective action schedule as completed, and site plan/survey plan)

- Waste disposition

- Closure verification results (data quality assessment and use restrictions)

- Conclusions and recommendations

- References

- Supporting documentation (sample analytical results, summary of radiological survey data, waste disposition documentation, and modifications to the SAFER Plan)

The final CR will be submitted to NNSA/NSO and NDEP for review and approval. This SAFER Plan and the subsequent CR will be available in the NNSA/NSO Public Reading facilities in Las Vegas, Nevada, and Carson City, Nevada, or by contacting the NNSA/NSO Project Manager. 


\subsection{INVESTIGATION/REMEDIATION WASTE MANAGEMENT}

All waste will be stored, sampled, analyzed, and disposed of according to all applicable state and federal regulations, the RCRA Part B Permit (NDEP, 1995), DOE Orders, and applicable M\&O procedures. The management of waste containers and each waste stream identified in this section will be discussed in greater detail in the CAU $116 \mathrm{WMP}$.

Title 40 CFR 265, Subpart I (EPA, 2003c), requires that all HW container storage areas must have a containment system. However, if the containers hold only wastes that do not contain free liquids and the containers are elevated or are otherwise protected from contact with accumulated liquid, the storage area need not have a containment system (40 CFR 264.175 [c][2]) (EPA, 2003b). Drums containing liquid wastes will be stored on spill containment pallets. Drums containing solid wastes may be stored on wood, metal, or spill containment pallets. Empty drums are not required to be staged on pallets.

All waste containers will be appropriately marked and/or labeled with the following information:

- Waste type

- Date of generation

- Appropriate warning labels (e.g., "Hazardous Waste" or "Caution, Contains Asbestos")

\subsection{WASTE MinimizATion}

Substantial reduction in the volume of LLW requiring disposal in the NTS LLW landfills will result from using the remaining basement structure of Building 3210 to contain the debris generated from the demolition of Building 3210 and, space permitting, as much demolition debris as possible. It is anticipated that the majority of debris generated from the demolition of the dewars and all other buildings and structures within the CAU boundary will qualify for disposal as sanitary waste. However, items from this debris found to be radiologically impacted above the surface and mass concentration limits for the Area 9 U10c Industrial Landfill will be managed appropriately and disposed of as LLW, according to the WMP. Items that contain significant economic value (e.g., cryogenic pumps, lead shielding, and/or electrical components) will be radiologically surveyed, decontaminated (if necessary and possible), and may be reused or recycled. Oils and other equipment fluids not containing hazardous/regulated or radiological constituents will be recycled. Re-use or recycling of equipment, material, and/or fluids will support a reduction of waste requiring disposal.

\subsection{Potential Waste Streams}

The waste streams to be generated during closure of CAU 116 are discussed in the following sections.

Waste that will be generated during the closure of CAU 116 will be characterized by laboratory analysis and/or process knowledge. Wastes will be sampled according to an approved SAP. The waste streams that will be generated during closure will be sufficiently characterized to facilitate proper disposal. 


\subsubsection{Hazardous Waste}

Materials identified during a 2003 inspection include lubricating oil, metallic lead (some of which may qualify for recycling), mercury switches, circuit boards, and metal foil. A more recent inspection conducted on February 28, 2006, by personnel (including a former NRDS project engineer) identified freon and ethylene glycol (antifreeze) as potentially being present as HW. HW will be properly characterized and transferred to the M\&O HW Organization for disposition according to the WMP.

Disposition pathways exist that permit solid lead removed from TCC to be reused or recycled within the DOE complex. With a significant quantity of solid lead to be removed from TCC, this option may create a substantial reduction in the total volume of HW or MW requiring disposal. ER and responsible waste management group will make the determination of whether to recycle the lead or dispose of the lead as HW or MW, based on quantity, contamination levels, and current demand for lead in the DOE recycling program. This re-use/recycle option does not include lead wool, shot, or lead solder.

All waste shipment and transportation documentation will be maintained in the project files. If final waste disposition occurs prior to the final CR being submitted, this evidence will be included in the CR. If shipment occurs after the CR is submitted, then the evidence will be maintained in the project files.

\subsubsection{Asbestos-Containing Material}

ACM is defined as material containing more than one percent asbestos by weight. Samples of all suspected ACM were collected and analyzed in April 2006. Analytical results confirmed that ACM is present as insulation on electrical cables and pipes, as floor/ceiling tiles, wall panels, transite box panels, and in mastic roofing sealant. The ACM insulation is located on the exterior and the interiors of the buildings. Some asbestos-insulated electrical cables are wrapped with a silver-colored metallic foil. Similar foil at the TCA facility was sampled and determined to contain hazardous levels of cadmium. Samples of this foil at TCC will be collected to determine if it also contains hazardous levels of cadmium. Non-radiologically impacted cadmium-containing foil, removed from the insulation, may be managed separately and disposed as HW. If radiologically impacted, this foil may also be managed as MW per Section 6.2.4.

All ACM will be removed by trained asbestos workers. ACM will be managed according to an approved asbestos management plan and M\&O CDs. After removal, ACM insulation will be double-bagged and containerized in 208-L (55-gal) steel drums or other acceptable waste containers. ACM insulation that is not radiologically impacted above the surface and mass concentration for the Area 9 U10c Industrial Landfill Permit and not wrapped in foil that has been determined to be hazardous will be disposed of onsite in the Area 23 Sanitary Landfill. Verification of disposal shall be presented in the CR. Area 23 Sanitary Landfill will only be used for non-radiological/non-hazardous asbestos waste. ACM wrapped in foil that is hazardous, but not radiologically impacted, will be managed according to the WMP and disposed of as HW.

\subsubsection{Asbestiform Low-Level Waste}

Based on previous surveys conducted at TCA where similar reactor testing took place, it is anticipated that a certain amount of ACM pipe insulation and mastic roofing sealant throughout 
TCC will be radiologically impacted. Due to the porous nature of the material, the waste will be characterized using ISOCS or by sampling. All ACM insulation determined to be radiologically impacted above the surface and mass concentration limits for the Area 23 Sanitary Landfill Permit and not wrapped with hazardous material (foil) will be managed as asbestiform LLW. All asbestiform LLW will be managed according to the WMP and DOE Guidance Document L-E10.302.LRM, Management Plan for the Disposal of Low-Level Waste with Regulated Asbestos Waste (DOE, 1999). The waste will be disposed of at an approved NTS LLW disposal site, according to NTS Waste Acceptance Criteria (WAC) requirements (NNSA/NSO, 2006). Verification of disposal shall be presented in the CR.

\subsubsection{Mixed Waste}

MW is waste containing both RCRA hazardous and low-level radioactive waste. Foil-covered asbestos has the potential for being an MW if the foil is determined to be hazardous and the foil or insulation is radiologically impacted, and the foil is not segregated from the radiologically impacted material. All hazardous/regulated radiologically impacted materials will be considered an MW. RCRA standards, Radiological Safe Work Practices, and Asbestos Handling procedures apply when handling waste generated at TCC. When staged onsite, MW will be stored in an approved 90-day waste accumulation area or a satellite accumulation area as described in the WMP.

Lead, mercury, or cadmium that are proven through sampling and/or surveys to be radiologically impacted and unable to be decontaminated or recycled will be managed appropriately, considered to be MW, and be disposed of according to the WMP.

\subsubsection{Low-Level Radioactive Waste}

Non-hazardous solid waste that exceeds the permissible radiological surface and mass concentration for the Area 9 U10c Industrial Landfill Permit will be managed as LLW. LLW generated at TCC will primarily consist of concrete, piping, and other miscellaneous building materials. Upon approval from NDEP, the remaining basement structure of Building 3210 will be filled with a considerable volume of LLW primarily from Building 3210 . Once the basement structure is filled, it will be mounded or capped, and closed in place with administrative controls. All demolition debris not placed in the basement structure will be managed and disposed of according to the WMP.

It is anticipated that the use of the Building 3210 basement structure for placement of LLW demolition debris will provide a significant reduction in the volume of LLW requiring disposal at an approved NTS LLW disposal site. The radiological activity of all LLW packages will be quantified using methods and procedures approved by Waste Generator Services.

Quantification of radiological activity is further discussed in the WMP. All LLW being disposed of at an NTS LLW disposal site will meet the NTS Waste Acceptance Criteria (NNSA/NSO, 2006). Verification of disposal shall be presented in the CR. 


\subsubsection{Non-Radiologically Impacted Polychlorinated Biphenyl Bulk Product Waste}

Due to the prevalent use of PCB-containing paint on interior surfaces, and with no plans to remove paint prior to demolition, waste generated from demolition of the TCC Facility may be managed as non-hazardous PCB bulk product waste per 40 CFR 761.62(b)(i), "Applied Dried Paints," (EPA, 2003e) or per Section 6.2.6.2. This debris will primarily consist of rubblized concrete, steel I-beams, electrical conduit, and stainless steel piping. Prior to demolition, the M\&O will request approval from NDEP to generate and entomb this debris in the basement structure. This approval will be obtained through approval of this CAU 116 SAFER Plan.

Fluorescent light ballasts contain PCBs. These items shall be removed and transferred to the M\&O HW Organization for offsite disposal as non-leaking PCB ballasts per 40 CFR 761.60(b)(2)(ii) (EPA, 2003d). No other PCB-containing items will be placed in packages containing PCB ballasts. Verification of disposal shall be presented in the CR.

\subsubsection{Radiologically Impacted Polychlorinated Biphenyl Bulk Product Waste}

PCB bulk product waste that exceeds the permissible radiological surface and mass concentration for the Area 9 U10c Industrial Landfill Permit will be managed as LLW. The majority of the debris that will be placed in the basement structure will be classified as radiologically impacted PCB bulk product waste. This waste will be managed according to the "Radioactive Waste Tracking, Handling, and Management at the NTS" operating procedure. Approval from NDEP will be required allowing the M\&O to fill the TCC basement with this debris. This approval will be obtained through approval of this CAU 116 SAFER Plan. Additional permits, if required, will be completed per NDEP direction. The approval and any additional permits will be included in the CAU 116 CR.

\subsubsection{Polychlorinated Biphenyl Fluids}

PCB-impacted fluids will be drummed, managed, and disposed of as TSCA-regulated PCB liquids. Storage and disposal requirements will be detailed in the WMP. Treatment of PCB-impacted articles is addressed in Section 4.2.2.4. PCB liquids found to be radiologically impacted will be managed and disposed of according to the WMP.

\subsubsection{Reusable or Recyclable Materials}

\subsubsection{Metallic Lead}

Lead items or materials will be removed from CAU 116 during closure activities. Items that contain solid lead include the steel-encapsulated lead shield doors, lead bricks, and lead plate. Solid lead will be removed, surveyed, and reused or recycled through the DOE Materials Recovery Program based in Oak Ridge, Tennessee, or be disposed as HW or MW. Whether to recycle the lead or dispose of it as HW or MW will be determined by ER and the responsible waste management group, based on quantity, contamination levels, and current demand for lead in the DOE recycling program. The re-use/recycle option does not include lead wool, shot, or solder. These forms of lead will be disposed of as HW or MW according to the WMP. 


\subsubsection{Used Oil}

Various pumps and associated delivery systems are located at the TCC Facility. These pumps and systems may contain lubricating fluids. Fluids need to be sampled and analyzed for PCBs, radiological constituents, and RCRA metals. If no COCs are detected above hazardous levels, the fluids will be removed and field screened for total halogenated solvents, using industry standard screening kits for chlorinated solvents. If field screenings indicate the material does not contain total halogenated solvents greater than 1,000 parts per million, the fluids will be managed as used oil and transferred to $\mathrm{M} \& \mathrm{O}$ Fleet for recycling. If field screenings indicate the material contains greater than 1,000 parts per million of total halogenated solvents, the fluids will be managed as HW, and the waste will be transferred to the M\&O HW Organization for offsite treatment and disposal. Verification of disposal or recycling shall be presented in the CR.

\subsubsection{Freon/Ethylene Glycol}

A recent site inspection conducted on February 28, 2006, by personnel including a former project engineer for the NRDS program identified freon and/or ethylene glycol (antifreeze) as potentially being present in a chiller unit in Building 3210 and in pumps in Building 3220.

All fluids will be drained, containerized, sampled, managed, and recycled or disposed of according to the WMP.

\subsubsection{Universal Waste}

Fluorescent light bulbs containing mercury are known to be present at the TCC Facility. Per 40 CFR 273.13(d) (EPA, 2003a), the bulbs will be managed as universal waste, and transferred to an offsite treatment, storage, and disposal facility. Verification of disposal shall be presented in the CR.

All universal waste will be managed according to applicable state and federal regulations and the WMP.

\subsubsection{Sanitary Waste}

Non-hazardous, solid waste items (e.g., equipment, piping, and/or scrap metal) that have been surveyed by RadCon and determined not to be radiologically impacted above the surface and mass concentrations for the Area 9 U10c Industrial Landfill may qualify for disposal as sanitary waste. All sanitary waste will be managed according to the WMP and disposed of at an approved NTS disposal site. Verification of disposal shall be presented in the CR. 
SAFER Plan - CAU 116

Section: Investigation/Remediation

Revision: 0

Date: July 2006

THIS PAGE INTENTIONALLY LEFT BLANK 


\subsection{QUALITY ASSURANCE/QUALITY CONTROL}

The overall objective of the closure activities described in this SAFER Plan is to collect accurate and defensible data to support the closure activities for CAU 116. Data shall be collected in the form of radiological surveys. Proper characterization and management of the waste streams produced during closure of CAU 116 will be verified by laboratory analysis.

The ISOCS will be used as a secondary tool to quantify radiological activity of waste containers or items. This tool is a portable gamma spectroscopy that uses a high-purity germanium crystal to quantify radiological activity of gamma-emitting nuclides. Use of this tool will follow stringent QC and data validation protocol. All supporting QC and data validation will be presented in the $\mathrm{CR}$, along with the analytical results for each waste item that is characterized.

\subsection{SAMPle Collection ACtivities}

All waste requiring additional characterization will be sampled and analyzed according to the SAP for CAU 116. At a minimum, the SAP will address the following:

- Sampling plan objectives

- DQO

- Confidence levels

- Precision

- Accuracy

- Representativeness

- Comparability

- Completeness

- Number and location of regular and QC samples

- Sampling technique

- Sampling equipment

All field observations and notes will be appropriately documented. All documented entries will be made with indelible ink. Field observations to be documented include:

- Time and date

- Sampler(s)

- Waste type and physical characteristics

- Sample locations cross-referenced to sample numbers

- Any deviations from the SAP

\subsection{APPLICABLE LABORATORY/ANALYTICAL DATA QUALITY INDICATORS}

Confirmation of achieving site closure objectives shall be provided by radiological surveys, as discussed in Section 4.2.8; however, laboratory analysis will be required for waste characterization samples. Analytical results from waste characterization samples will be verified and validated according to established procedures and with the requirements specified in this 
SAFER Plan. All laboratory data from waste characterization samples will be evaluated for data quality according to EPA Functional Guidelines, DQO, and the SAP. The data will be reviewed to ensure that all critical samples were appropriately collected and analyzed and that the results passed data validation criteria.

DQIs are qualitative and quantitative statements that specify the data requirements of a project. The DQIs for CAU 116 include precision, accuracy/bias, representativeness, comparability, completeness, and sensitivity. These DQIs are discussed in the following sections, summarized in Table 6, and will be addressed in the SAP for CAU 116.

\subsubsection{Precision}

Precision measures the reproducibility of data under a given set of conditions. It is a quantitative measurement of the variability of a population of measurements compared to their average value. Precision applies to parameters sampled and analyzed in duplicate.

Precision will be assessed by collecting one duplicate sample for every 20 regular samples. Duplicate samples will be collected and analyzed for each media and analyte. Analytical precision will be monitored through analysis and evaluation of laboratory duplicates.

\subsubsection{Accuracy/Bias}

Accuracy measures the degree of difference between measured or calculated values of a parameter and the true value of that parameter. The closer the measurement is to the true value, the more accurate the measurement.

Accuracy can be affected by sampling uncertainty and measurement uncertainty. Implementation of the CAU 116 SAP will maximize accuracy by identifying standardized procedures to collect samples. The SAP will also incorporate QCs, sample tracking, and standard analysis to increase accuracy by decreasing overall uncertainty.

\subsubsection{Representativeness}

Representativeness is a qualitative measure of the degree to which the sample data accurately and precisely represent a characteristic of a sample population or environmental condition.

Representativeness will be attained by ensuring that the sample locations, analytical parameters, analytical methods, sampling protocols, and sample handling all meet the project-specific objective.

\subsubsection{Comparability}

Comparability is a qualitative measure that expresses the confidence that one data set can be compared to another. It will be achieved by adhering to the standardized field sampling procedures. The same analytical laboratory will perform the same analyses for all samples. All samples will be collected using M\&O standard methods of sample collection. Sample results will be reported in standard units to allow for comparison of the data. 


\subsubsection{Completeness}

Date: July 2006

Completeness is a quantitative measure of data quality expressed as the percentage of valid data obtained that satisfies the project-specific requirements. Since a limited number of samples will be collected to characterize the waste, 100 percent of the data collected must be of acceptable quality to allow for proper characterization of the waste streams.

Table 6. Laboratory/Analytical Data Quality Indicators

\begin{tabular}{|c|c|c|}
\hline $\begin{array}{l}\text { DATA QUALITY } \\
\text { INDICATOR }\end{array}$ & PERformance Criteria & $\begin{array}{c}\text { IMPACT ON DECISION IF PERFORMANCE } \\
\text { CRITERIA NOT MET }\end{array}$ \\
\hline Precision & $\begin{array}{l}\text { Variations between duplicates (field and lab) } \\
\text { and original sample should not exceed } \\
\text { analytical method-specific criteria. }\end{array}$ & $\begin{array}{l}\text { Estimated data within sample delivery group } \\
\text { (SDG) will be evaluated for their usability. If } \\
\text { data are determined to be unusable, data will not } \\
\text { be used in decision and completeness criteria will } \\
\text { be assessed. }\end{array}$ \\
\hline Accuracy/bias & $\begin{array}{l}\text { Laboratory control sample results and matrix } \\
\text { spike results should be within analytical } \\
\text { method-specific criteria. }\end{array}$ & $\begin{array}{l}\text { Estimated data within sample delivery group will } \\
\text { be evaluated for its usability. If estimated data } \\
\text { are biased high or conservative, the data may be } \\
\text { used in decision. If estimated data are biased low } \\
\text { and below the decision threshold, the data may } \\
\text { not be used in decision and completeness criteria } \\
\text { will be assessed. }\end{array}$ \\
\hline $\begin{array}{l}\text { Representativene } \\
\text { ss }\end{array}$ & $\begin{array}{l}\text { Correct analytical method performed for } \\
\text { appropriate COC: valid data reflects } \\
\text { appropriate target population. }\end{array}$ & $\begin{array}{l}\text { Cannot identify COC or estimate concentration } \\
\text { of COC; therefore, cannot make decision(s) on } \\
\text { target population. }\end{array}$ \\
\hline Comparability & $\begin{array}{l}\text { Equivalent samples analyzed using same } \\
\text { analytical methods, same units of } \\
\text { measurement, and detection limits must be } \\
\text { used for like analyses. }\end{array}$ & Inability to use data collected. \\
\hline Completeness & $\begin{array}{l}100 \% \text { of samples submitted to laboratory } \\
100 \% \text { of requested analyses performed } \\
100 \% \text { of critical analytes to be valid }{ }^{\mathrm{a}} \\
80 \% \text { of non-critical analytes to be valid }\end{array}$ & $\begin{array}{l}\text { 1. Decision of whether extent of contamination } \\
\text { has been bounded cannot be determined. } \\
\text { Impacts to decisions will be assessed. } \\
\text { 2. Decision of whether COC above action levels } \\
\text { remain in soil cannot be determined. Impacts } \\
\text { to decisions will be assessed. }\end{array}$ \\
\hline Sensitivity & $\begin{array}{l}\text { Detection limits of laboratory instruments } \\
\text { must be less than action level for COC. }\end{array}$ & $\begin{array}{l}\text { Cannot determine if COC are present at levels of } \\
\text { concern, thereby investigation objectives cannot } \\
\text { be met }\end{array}$ \\
\hline
\end{tabular}

Source: Industrial Sites Quality Assurance Project Plan (NNSA/NV, 2002)

${ }^{a}$ Critical analytes are those analytes most likely present in the target population at COC, which have been identified through process knowledge of similar sites and historical documentation.

\subsubsection{Sensitivity}

Sensitivity is the capability of a method or instrument to discriminate between measurement responses representing different levels of a variable of interest. This indicator is determined from the value of the standard deviation at the concentration level of interest. It represents the minimum difference of concentration that can be distinguished between two samples with a high degree of confidence. Sensitivity must be sufficient to detect contaminants at or below decision levels. Sensitivity will be achieved by analyzing all samples using the appropriate analytical laboratories, methods, and instruments. 
SAFER Plan - CAU 116

Section: Investigation/Remediation

Revision: 0

Date: July 2006

THIS PAGE INTENTIONALLY LEFT BLANK 


\subsection{REFERENCES}

DOE, see U.S. Department of Energy.

EPA, see U.S. Environmental Protection Agency.

FFACO, see Federal Facility Agreement and Consent Order.

Federal Facility Agreement and Consent Order, 1996 (as amended). Agreed to by the State of Nevada, U.S. Department of Energy, and U.S. Department of Defense.

Murphy, T., Nevada Division of Environmental Protection. 2004. Letter to R. M. Bangerter, Jr. (NNSA/NSO) entitled, "Review of Industrial Sites Project Document 'Guidance for Calculating Industrial Sites Project Remediation Goals for Radionuclides in Soil Using the Residual Radiation (RESRAD) Computer Code,"” 19 November. Las Vegas, NV.

NDEP, see Nevada Division of Environmental Protection.

NCRP, see National Council on Radiation Protection and Measurements.

NNSA/NSO, see U.S. Department of Energy, National Nuclear Security Administration Nevada Site Office

National Council on Radiation Protection and Measurements. 1999. Recommended Screening Limits for Contaminated Surface Soil and Review of Factors Relevant to Site-Specific Studies, Report No. 129. Bethesda, MD.

Nevada Division of Environmental Protection. 1995. "Permit for a Hazardous Waste Management Facility Number NEV HW009.” U.S. Department of Energy Nevada Operations Office, Nevada Test Site.

U.S. Department of Energy. 1989. A Manual for Implementing Residual Radioactive Material Guidelines, DOE/CH-8901. Washington, D.C.

U.S. Department of Energy. 1993. Radiation Protection of the Public and the Environment, Rev. 2. DOE Order 5400.5. Washington, D.C.

U.S. Department of Energy. 1999. Management Plan for the Disposal of Low-Level Waste with Regulated Asbestos Waste, L-E10.302.LRM. Washington, D.C.

U.S. Department of Energy, National Nuclear Security Administration Nevada Operations Office. 2002. Industrial Sites Quality Assurance Project Plan, Rev. 3, DOE/NV--372. Las Vegas, NV

U.S. Department of Energy, National Nuclear Security Administration Nevada Site Office. 2004a. Facility Decontamination and Decommissioning Program Surveillance and Maintenance Plan, Rev. 1. DOE/NV/11718--221. Las Vegas, NV.

U.S. Department of Energy, National Nuclear Security Administration Nevada Site Office. 2004b. NV/YMP Radiological Control Manual, Rev. 5. DOE/NV/11718--079. Las Vegas, NV.

U.S. Department of Energy, National Nuclear Security Administration Nevada Site Office. 2006. Nevada Test Site Waste Acceptance Criteria, Rev. 6, DOE/NV-325.

Las Vegas, NV. 


\subsection{REFERENCES (continued)}

U.S. Environmental Protection Agency. 1996. Test Methods for Evaluating Solid Waste Physical /Chemical Methods, SW-846, $3^{\text {rd }}$ Edition. Washington, D.C.

U.S. Environmental Protection Agency. 2000. Guidance for the Data Quality Objective Process, EPA QA/G4. Washington, D.C.

U.S. Environmental Protection Agency. 2001. Title 40 Code of Federal Regulations, Part 260.24, "Toxicity Characteristics." Washington, D.C.

U.S. Environmental Protection Agency. 2003a. Title 40 Code of Federal Regulations, Part 273.13, "Waste Management." Washington, D.C.

U.S. Environmental Protection Agency. 2003b. Title 40 Code of Federal Regulations, Part 264.175, "Containment." Washington, D.C.

U.S. Environmental Protection Agency. 2003c. Title 40 Code of Federal Regulations, Part 265, "Interim Status Standards for Owners and Operators of Hazardous Waste Treatment, Storage, and Disposal Facilities." Washington, D.C.

U.S. Environmental Protection Agency. 2003d. Title 40 Code of Federal Regulations, Part 761.60, "Disposal Requirements." Washington, D. C.

U.S. Environmental Protection Agency. 2003e. Title 40 Code of Federal Regulations, Part 761.62, “Disposal of PCB Bulk Product Waste." Washington, D. C.

U.S. Environmental Protection Agency. 2003f. Title 40 Code of Federal Regulations, Part 761.79, "Decontamination Standards and Procedures.” Washington, D. C.

U.S. Environmental Protection Agency. 2004 Region 9 Preliminary Remediation Goals (PRGs). As accessed at http://www.epa.gov/region09/waste/sfund/prg/index.htm on 30 March 2006. Prepared by S. J. Smucker. San Francisco, CA. 
SAFER Plan - CAU 116

Section: Appendix A

Revision: 0

Date: July 2006

\section{APPENDIX A. PROJECT ORGANIZATION}


SAFER Plan - CAU 116

Section: Appendix A

Revision: 0

Date: July 2006

THIS PAGE INTENTIONALLY LEFT BLANK 


\section{PROJECT ORGANIZATION}

The U.S. Department of Energy, National Nuclear Security Administration Nevada Site Office (NNSA/NSO) Project Manager or Task Manager will serve as the primary point of contact for all activities conducted in this project. The NNSA/NSO Project Manager is responsible for seeing that all activities conducted during the project fulfill the obligations of NNSA/NSO as described in the Federal Facility Agreement and Consent Order (FFACO) of 1996 and the Nevada Division of Environmental Protection (NDEP)-approved work plan. The NNSA/NSO Project Manager will plan, authorize, and control project work so that activities are completed in accordance with the work plan on schedule and within budget. The NNSA/NSO Project Manager will be the primary point of contact with the NDEP. The NNSA/NSO points of contact for this project are as follows:

\section{Federal Industrial Sites Sub-Project Director Environmental Restoration Project:}

Kevin Cabble

Telephone Number: (702) 295-5000

\section{Federal Project Director}

Environmental Restoration Project:

Janet Appenzeller-Wing

Telephone Number: (702) 295-0461

The identification of the project Health and Safety Officer and the Quality Assurance Officer can be found in both the Field Management Plan and the Site-Specific Health and Safety Plan. However, personnel are subject to change, and it is suggested that the appropriate NNSA/NSO Project Manager be contacted for further information. The Task Manager will be identified in the FFACO Monthly Activity Report prior to the start of field activities. 
SAFER Plan - CAU 116

Section: Appendix A

Revision: 0

Date: July 2006

THIS PAGE INTENTIONALLY LEFT BLANK 
Revision: 0

Date: July 2006

\section{APPENDIX B.}

\section{NEVADA DIVISION OF ENVIRONMENTAL PROTECTION COMMENTS}


SAFER Plan - CAU 116

Section: Appendix B

Revision: 0

Date: July 2006

THIS PAGE INTENTIONALLY LEFT BLANK 
SAFER Plan - CAU 116

Section: Appendix B

Revision: 0

Date: July 2006

\section{LIBRARY DISTRIBUTION LIST}


SAFER Plan - CAU 116

Section: Distribution List

Revision: 0

Date: July 2006

THIS PAGE INTENTIONALLY LEFT BLANK 


\section{LIBRARY DISTRIBUTION LIST}

U.S. Department of Energy

National Nuclear Security Administration

Nevada Site Office

Technical Library

P.O. Box 98518, M/S 505

Las Vegas, NV 89193-8518

U.S. Department of Energy

Office of Scientific and Technical Information

P.O. Box 62

Oak Ridge, TN 37831-0062

Southern Nevada Public Reading Facility

c/o Nuclear Testing Archive

P.O. Box 98521, M/S 400

Las Vegas, NV 89193-8521

Manager, Northern Nevada FFACO

Public Reading Facility

c/o Nevada State Library \& Archives

Carson City, NV 89701-4285
1 (Uncontrolled)

1 (Uncontrolled, electronic copy)

2 (Uncontrolled, electronic copy)

1 (Uncontrolled, electronic copy) 
SAFER Plan - CAU 116

Section: Library Distribution List

Revision: 0

Date: July 2006

THIS PAGE INTENTIONALLY LEFT BLANK 